(C) 2022, The Authors. Published by Elsevier Inc. and Fass Inc. on behalf of the American Dairy Science Association ${ }^{\circledR}$. This is an open access article under the CC BY license (http://creativecommons.org/licenses/by/4.0/).

\title{
Composition and aptitude for cheese-making of milk from cows, buffaloes, goats, sheep, dromedary camels, and donkeys
}

\author{
Giovanni Bittante, ${ }^{1}$ Nicolò Amalfitano, ${ }^{1}$ Matteo Bergamaschi, ${ }^{1}$ Nageshvar Patel, ${ }^{1}$ Mohamed-Laid Haddi, ${ }^{2}$ \\ Hamida Benabid, ${ }^{3}$ Michele Pazzola, ${ }^{4}$ Giuseppe Massimo Vacca, ${ }^{5}$ Franco Tagliapietra, ${ }^{1 *}$ \\ and Stefano Schiavon ${ }^{1}$ \\ ${ }^{1}$ DAFNAE—Department of Agronomy, Food, Natural resources, Animals and Environment, University of Padova (Padua), 35020 Legnaro (PD), \\ Italy \\ ${ }^{2}$ Laboratoire de Mycologie, Biotechnologie et Activité Microbienne, Université des Frères Mentouri, Constantine 25000, Algeria \\ ${ }^{3}$ Institut de Nutrition, Alimentation et Technologies Agro-Alimentaires, Université des Frères Mentouri, Constantine 25000, Algeria \\ ${ }^{4}$ Department of Animal Biology, University of Sassari, 07100 Sassari, Italy \\ ${ }^{5}$ Department of Veterinary Medicine, University of Sassari, 07100 Sassari, Italy
}

\begin{abstract}
Bovines produce about $83 \%$ of the milk and dairy products consumed by humans worldwide, the rest represented by bubaline, caprine, ovine, camelid, and equine species, which are particularly important in areas of extensive pastoralism. Although milk is increasingly used for cheese production, the cheese-making efficiency of milk from the different species is not well known. This study compares the cheese-making ability of milk sampled from lactating females of the 6 dairy species in terms of milk composition, coagulation properties (using lactodynamography), curd-firming modeling, nutrients recovered in the curd, and cheese yield (through laboratory model-cheese production). Equine (donkey) milk had the lowest fat and protein content and did not coagulate after rennet addition. Buffalo and ewe milk yielded more fresh cheese (25.5 and $22.9 \%$, respectively) than cow, goat, and dromedary milk $(15.4,11.9$, and $13.8 \%$, respectively). This was due to the greater fat and protein contents of the former species with respect to the latter, but also to the greater recovery of fat in the curd of bubaline $(88.2 \%)$ than in the curd of camelid milk $(55.0 \%)$ and consequent differences in the recoveries of milk total solids and energy in the curd; protein recovery, however, was much more similar across species (from $74.7 \%$ in dromedaries to $83.7 \%$ in bovine milk). Compared with bovine milk, the milk from the other Artiodactyla species coagulated more rapidly, reached curd firmness more quickly (especially ovine milk), had a more pronounced syneresis (especially caprine milk), had a
\end{abstract}

Received July 2, 2021

Accepted November 4, 2021.

*Corresponding author: franco.tagliapietra@unipd.it greater potential asymptotical curd firmness (except dromedary and goat milk), and reached earlier maximum curd firmness (especially caprine and ovine milk). The maximum measured curd firmness was greater for bubaline and ovine milk, intermediate for bovine and caprine milk, and lower for camelid milk. The milk of all ruminant species can be used to make cheese, but, to improve efficiency, cheese-making procedures need to be optimized to take into account the large differences in their coagulation, curd-firming, and syneresis properties.

Key words: milk coagulation, curd firmness, syneresis, cheese composition, dairy species

\section{INTRODUCTION}

The world's supply of milk is provided by just a few species. Aside from cattle, accounting for $83 \%$ of world milk production, buffaloes represent $13 \%$ of production, goats $2 \%$, sheep 1\%, and camels $0.4 \%$ (FAO, 2019). The remaining share is provided by other less-common dairy species, such as equines (horses and donkeys), yak, and reindeer (Park et al., 2017).

Cattle are raised in a wide range of environments. Some dairy species can be raised in what for others would be adverse environmental conditions, making dairying possible in environments that are often unable to support any other type of agricultural production. Milk can be produced from buffaloes in mainly wet tropical regions, goats in regions with poor soils such as in Africa but also in fertile areas of developed countries, sheep in semi-arid regions around the Mediterranean, camels in the very arid lands of North Africa and Asia, equines in the steppes of Central Asia, and yak and reindeer in environments that are very cold due to extreme altitudes or latitudes (FAO, 2019). The distribution of different dairy species around the world depends on 


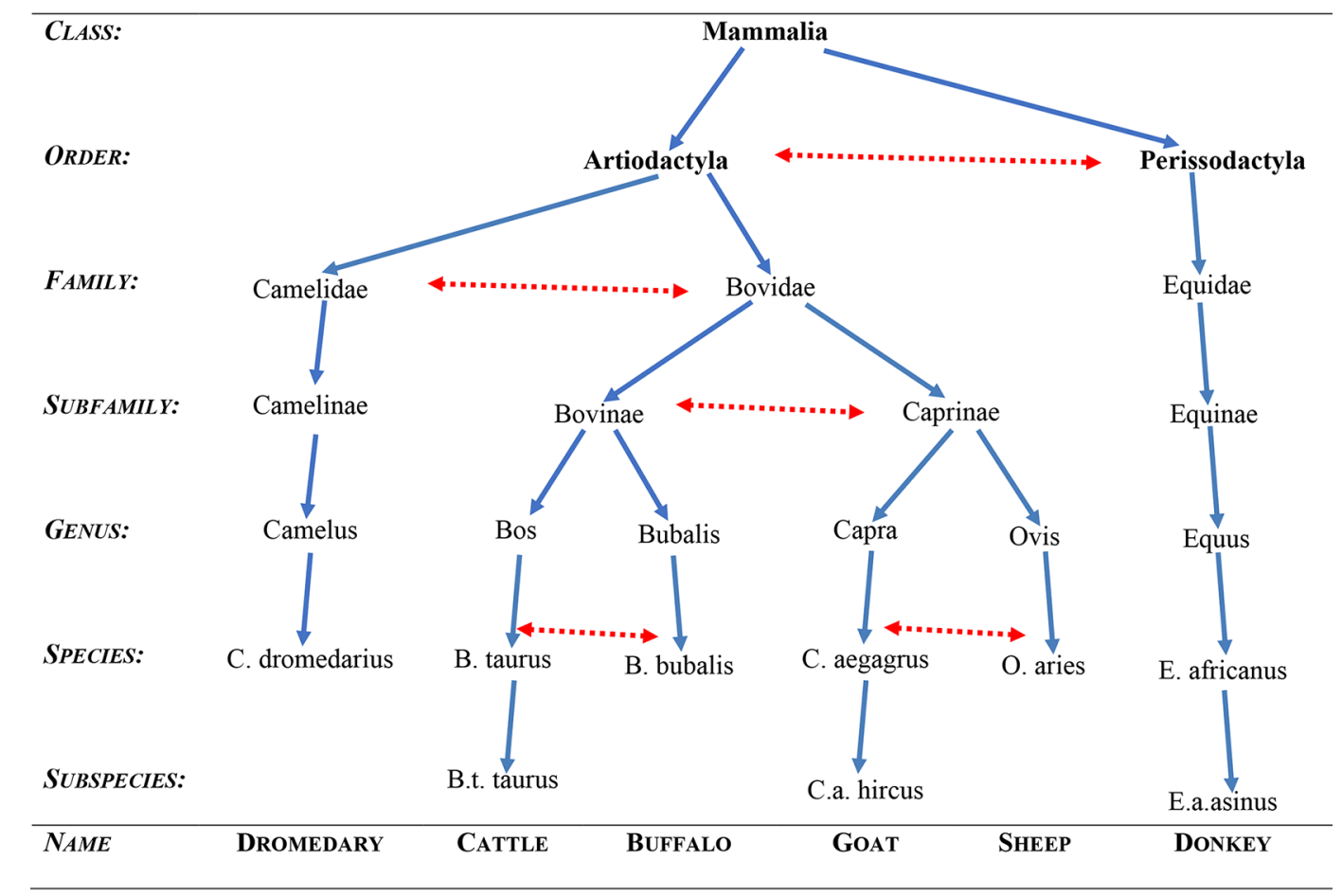

Figure 1. Evolutionary taxonomy of the 6 major dairy species and orthogonal contrasts among them (dashed red arrows).

their ability to adapt to harsh (cold, hot, arid, humid) environments, available feed resources, socioeconomic conditions, and human dietary traditions and cultural heritages. In developing countries, non-bovine species represent one-third of the milk consumed by the local population (40\% in Asia) and probably about half of the milk fat and protein. As is well known, the main dairy species belong to the order Artiodactyla, the family Bovidae, and the 2 subfamilies Bovinae (cattle and buffalo) and Caprinae (sheep and goats), all of which are ruminants. As Figure 1 shows, camels belong to the same order but to a different family (Camelidae), and they are pseudoruminants, having 3 stomachs. Last, equines are very different from the other species, being monogastric and members of the order Perissodactyla and the family Equidae.

Processing allows milk to be preserved for periods ranging from days to years; it helps reduce food-borne illness (FAO, 2019) and often also the effects of lactose intolerance, which affects about two-thirds of the human population (Lomer et al., 2008). Cheese consumption is increasing worldwide (IDF, 2020). A wide range of cheese-making procedures are employed in different areas of the world and according to the species producing the milk. In the European Union alone, 238 different types of cheeses have protected designation of origin or protected geographical indication certification (Dias and Mendes, 2018). The authors are aware of only a few studies comparing the cheese-making aptitude of milk from different species (usually sheep and goats) using the same procedures, although large variability has been found according to breed within species (Cecchinato et al., 2015; Stocco et al., 2017, 2018a). The composition of milk varies greatly from species to species (reviewed by Alston-Mills, 1995; Medhammar et al., 2012; and Faccia et al, 2020a), as well as in relation to their phylogenetic pathways (Oftedal and Iverson, 1995). It is worth mentioning that the data reported in the original articles cited in these reviews were often obtained from a few samples taken from individual animals from a single or a few farms, and that the sampling, conservation, and analytical methods sometimes differ. Only a few original studies have directly compared the composition of milk from different species, usually bovine, ovine, and caprine (Gelè et al., 2014; Legarto et al., 2014; Roy et al., 2020).

Moreover, the technological properties (coagulation, curd firming, syneresis) of milk from different species have seldom been compared (Calvo and Balcones, 2000; Roy et al., 2020), and it is not known whether taxonomic distance also affects these traits. One problem that arises in evaluating the technological properties of milk from different species is that the methodologies commonly used in both research and industry have been established for testing bovine milk, and may not be always reliable when applied to other species. 
Recently, it has been shown that modeling the dynamic patterns of milk coagulation, curd firming, and syneresis is more useful than using single-point traits to analyze the technological properties of bovine milk (Cecchinato et al., 2013) and could also be useful for analyzing the technological properties of milk from other species (Pazzola et al., 2018). Moreover, laboratory model cheese-making procedures mimicking those used in the dairy industry have been used to study cheeses made from milk from different species (Cipolat-Gotet et al., 2016a; Stocco et al., 2018a). Therefore, new opportunities are available for studying and comparing the cheese-making aptitude of milk from different dairy species. However, it should be borne in mind that where differences in species occur, there are also differences in environments and dairy systems, in farms within dairy systems, and in lactating animals within farms.

We therefore carried out a preliminary study on the 6 major dairy species in their typical environments and dairy systems, using bulk milk samples from different farms, each consisting of milk from many lactating females, with the aim of evaluating the variability in cheese-making efficiency found in practice. The specific aims of this study were to compare the different types of milk in terms of (1) chemical composition; (2) coagulation, curd-firming patterns, and syneresis properties; (3) recovery of milk nutrients in the curd; and (4) cheese yields, while also considering their phylogenetic pathways.

\section{MATERIALS AND METHODS}

\section{Herds, Animals, and Milk Samples}

A total of fifty-four 2.5-L bulk milk samples (10-13 per species) were obtained after the morning milking from the milk tanks at various dairy farms rearing cows, buffaloes, goats, ewes, and donkeys in different regions of Italy. In addition, ten 2.0-L milk samples were obtained from free-ranging dromedary camels in 2 grazing areas of the province of Biskra in Algeria (Haddi et al., 2003): these animals were hand-milked and the samples immediately refrigerated. The farms were representative of the major dairy systems of the 5 species sampled in Italy and the dromedary camels sampled in North Africa. The main characteristics of the rearing environments, climatic conditions, farms, feeding systems, and animals (breed, size, production) are summarized in Table 1. This information is intended to give an overview of the major differences among the dairy species, as it is beyond the scope of this study to analyze these characteristics in detail.

All the milk samples, without preservative, were chilled at the farm and transported using a portable refrigerator (set at $6 \pm 2^{\circ} \mathrm{C}$ ) to the Milk Laboratory of the Department of Agronomy, Food, Natural Resources, Animals and Environment (DAFNAE) of the University of Padova (Legnaro, Italy). They were mixed, aliquoted, and processed within $48 \mathrm{~h}$ of sampling.

\section{Analysis of Milk Samples}

All milk and whey samples were analyzed using the following methods: percent fat content according to the Weibull-Stoldt method and Soxhlet extraction (VDLUFA, 2003); percent protein content according to the method 991.20 (nitrogen total content by Kjeldahl $\times$ 6.38; AOAC International, 1995); percent casein content according to AOAC International (1995) method no. 927.03; casein number, expressed as casein as percent of total protein; percent lactose content by HPLC (Schuster-Wolff-Bühring et al., 2011); percent ash content according to AOAC International (1995) method no. 945.46); percent total solids content according to AOAC International (1995) method no. 925.23. Energy content of the milk and whey samples $(\mathrm{MJ} / \mathrm{kg}$ ) was estimated by an equation based on their fat, protein and lactose contents, as proposed by NRC (2001); the results were then converted to megajoules. Sample pH was measured with a Titralab AT1000 Series analyzer fitted with a PHC805 pH electrode (Hach Company), and SCC was measured with a Fossomatic Minor (Foss A/S) and then log-transformed to SCS.

\section{Single-Point Milk Coagulation Properties and Modeling of Curd Firmness and Syneresis}

The milk coagulation properties of each milk sample were measured in duplicate (128 trials) by mechanical lactodynamograph (2 Formagraph instruments, Foss Electric A/S). Pendula calibration was carried out before each session of the trial. For each animal replicate, $10 \mathrm{~mL}$ of milk was heated to $35^{\circ} \mathrm{C}$ and then mixed with $200 \mu \mathrm{L}$ of bovine rennet solution (Hansen Standard 215 with $80 \pm 5 \%$ chymosin and $20 \pm 5 \%$ pepsin; Pacovis Amrein AG) freshly diluted to $1.2 \%$ (wt/vol) in distilled water. All milk samples coagulated within 60 min of rennet addition, except for the donkey milk samples, none of which coagulated. At the same time, we carried out a small trial only on donkey milk, in which the experimental conditions were modified to stimulate milk gelation. Neither doubling the rennet concentration, lowering the $\mathrm{pH}$ (using citric acid) to a range of 5.3 to 5.5 , or prolonging the time interval to $3 \mathrm{~h}$ from rennet addition, resulted in coagulation of donkey milk.

The following traditional single-point measurements of each coagulated milk sample replicate were obtained 
Bittante et al.: CHEESE-MAKING WITH MILK FROM DIFFERENT SPECIES

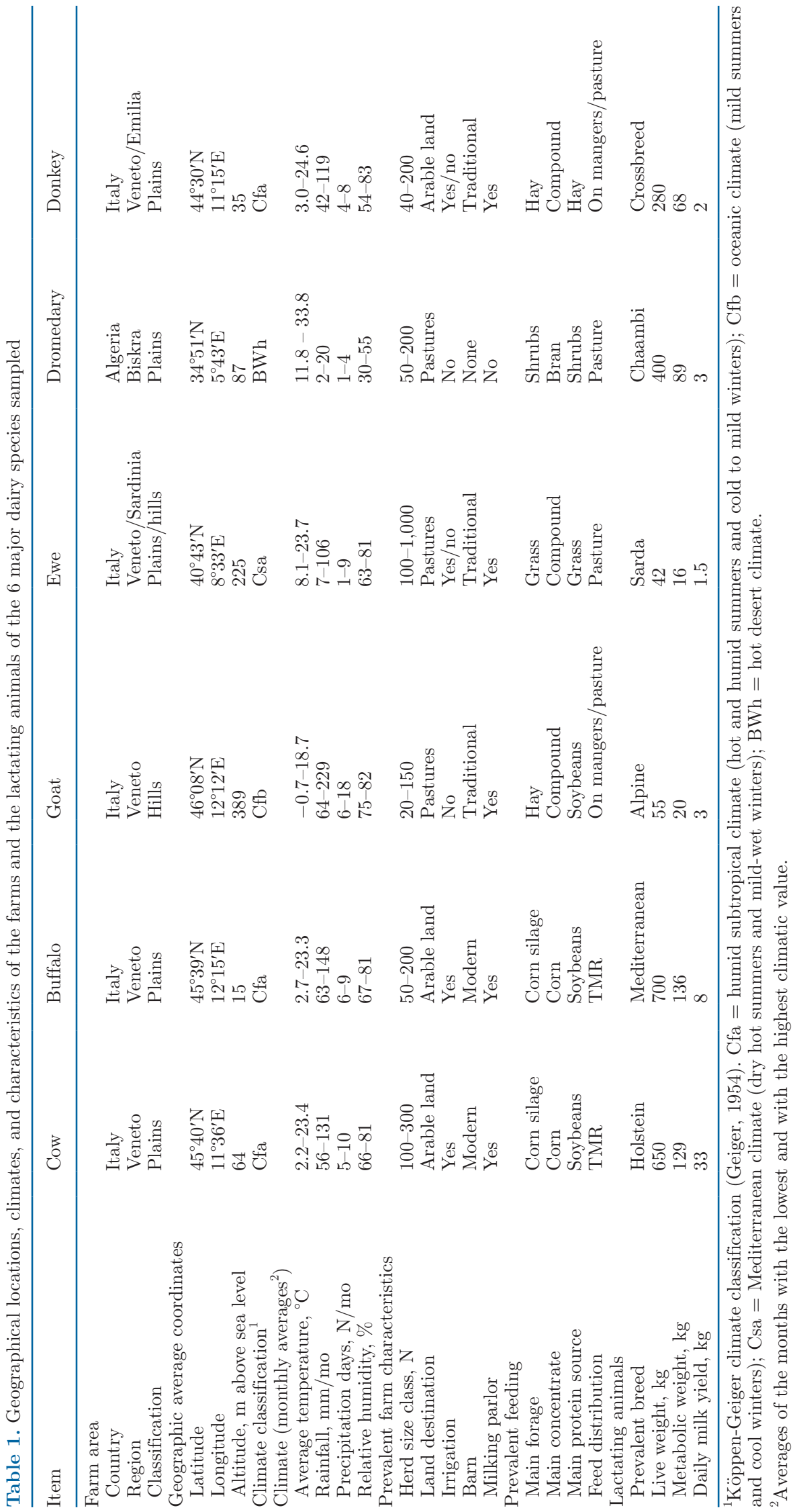


directly from the instruments: rennet coagulation time (RCT, min) from rennet addition to gelation; time interval between gelation and reaching a curd firmness of $20 \mathrm{~mm}\left(\mathbf{k}_{\mathbf{2 0}}, \mathbf{m i n}\right)$; curd firmness at 30,45 , and $60 \mathrm{~min}$ after rennet addition $\left(\mathbf{a}_{30}, \mathbf{a}_{45}\right.$, and $\left.\mathbf{a}_{60}, \mathrm{~mm}\right)$.

A data file of the 240 curd firmness (CF) observations (1 every $15 \mathrm{~s}$ for the $60 \mathrm{~min}$ of the test) for each milk replicate was also built for modeling $\mathrm{CF}$ over time following rennet addition $\left(\mathbf{C F}_{\mathbf{t}}\right)$. The 4-parameter model (Bittante et al., 2013) was chosen for this study because a preliminary inspection of the $\mathrm{CF}_{\mathrm{t}}$ data showed an appreciable decrease in $\mathrm{CF}$ in the final part of the curve of almost all the coagulated milk samples, with the exception of some bovine and dromedary milk samples. This modeling uses all the information available to estimate 4 equation parameters for each sample replicate, which, unlike traditional milk coagulation properties, are not single-point measurements. The following model was adopted:

$$
\mathrm{CF}_{\mathrm{t}}=\mathrm{CF}_{\mathrm{P}} \times\left[1-e^{-\mathrm{k}_{\mathrm{CF}} \times(\mathrm{t}-\mathrm{RCT})}\right] \times e^{-\mathrm{k}_{\mathrm{SR}} \times\left(\mathrm{t}-\mathrm{RCT}_{\mathrm{eq}}\right)} .
$$

The equation parameters estimated for each milk replicate were as follows: $\mathbf{C F}_{\mathbf{P}}(\mathrm{mm})$, the asymptotical potential value of $\mathrm{CF}$ at an infinite time $(\mathrm{mm})$ in absence of syneresis; $\mathbf{k}_{\mathbf{C F}}(\% / \mathrm{min})$, the curd-firming instant rate constant describing the increase in $\mathrm{CF}$ over time; $\mathbf{k}_{\mathrm{SR}}(\% / \mathrm{min})$, the syneresis instant rate constant describing the decrease in $\mathrm{CF}$ over time (an apparent decrease due to the increasing quantity of whey in the vat expelled from the curd); and $\mathbf{R C T}_{\mathbf{e q}}(\mathrm{min}), \mathrm{RCT}$ estimated by the $\mathrm{CF}_{\mathrm{t}}$ equation on the basis of all data points.

The $\mathrm{CF}_{\mathrm{P}}$ is conceptually independent of test duration and is not intrinsically dependent on RCT (unlike $\mathrm{a}_{30}, \mathrm{a}_{45}$, and $\mathrm{a}_{60}$ ). In the initial phase of the test, after gelation, $\mathrm{k}_{\mathrm{CF}}$ prevails over $\mathrm{k}_{\mathrm{SR}}$, such that $\mathrm{CF}_{\mathrm{t}}$ increases to a point in time $\left(\mathbf{t}_{\max }\right)$ at which the effects of the 2 parameters are equal but opposite in sign; this is when $\mathrm{CF}_{\mathrm{t}}$ reaches its maximum level $\left(\mathbf{C F}_{\text {max }}\right)$. Thereafter, $\mathrm{CF}_{\mathrm{t}}$ decreases, tending toward a null value.

\section{Model Cheese-Making Procedure to Measure Nutrient Recoveries in the Curd and Cheese Yields}

A total of 64 laboratory cheese-makings with complete material balances were carried out. The cheesemaking apparatus consisted of 2 water baths fitted with a digital temperature controller and pumps to mix the water to ensure homogeneous heat distribution throughout the water baths. Five stainless-steel vats (capacity 2,000 mL) were filled with 1,500 mL of milk from each species and placed in a water bath (except for the buffalo milk, where $800 \mathrm{~mL}$ was used because of the higher cheese yield, and milk samples were analyzed in 2 replicates). The steps in the model cheese-making procedure adopted are summarized in Figure 2, and are described in detail in a previous study (Cecchinato et al., 2013) with a few modifications. Hansen Naturen Plus 215 bovine rennet (Pacovis Amrein AG) was added to the milk. The cheese wheels were ripened for $90 \mathrm{~d}$ in a climatic chamber at $15^{\circ} \mathrm{C}$ and $85 \%$ relative humidity. During ripening the wheels were vacuum-packed $(7 \mathrm{~d}$ after cheese-making) until the end of ripening.

Cheese-making traits were calculated from the weights of the milk and the whey (in grams) and their chemical compositions, as proposed in a previous study (Cecchinato et al., 2015). The composition of the curd was calculated by subtracting the weight of each nutrient in the whey from the weight of the corresponding nutrient in the milk processed. In addition, ripened cheese yield was calculated from the weight of the ripened cheese wheels, according the method described by Cipolat-Gotet et al. (2020).

Briefly, the cheese-yield (\%CY) and nutrient recovery (REC) traits measured were as follows:

- $\% \mathrm{CY}_{\mathrm{CURD}}, \% \mathrm{CY}_{\text {SOLIDS }}$, and $\% \mathrm{CY}_{\text {WATER }}(\%)$, calculated as the percentage ratios of the weights $(\mathrm{g})$ of the fresh curd, curd dry matter, and curd water, respectively, to the weight of the milk processed $(\mathrm{g})$;

- $\mathrm{REC}_{\text {PRoteIN }}, \mathrm{REC}_{\mathrm{FAT}}$, and $\mathrm{REC}_{\mathrm{SOLIDS}}(\%)$, calculated as the percentage ratios between the weights (g) of the protein, fat, and dry matter in the curd, respectively, and the corresponding components in the milk processed $(\mathrm{g})$;

- $\mathrm{REC}_{\text {ENERGy }}(\%)$, calculated as the percentage ratio between the energy content of the curd and the energy content of the milk processed;

- $\% \mathrm{CY}_{\mathrm{CHEESE}}(\%)$, calculated as the percentage ratio of the weight $(\mathrm{g})$ of each cheese wheel after ripening to the weight of the corresponding milk processed (g).

\section{Statistical Analyses}

Nonlinear regressions were fitted to the $240 \mathrm{CF}_{\mathrm{t}}$ observations available for each milk sample replicate using the SAS version 9.4 nonlinear procedure (PROC NLIN; SAS Institute Inc.). The parameters of each individual equation were estimated by the Marquardt iterative method (350 iterations and a 10-5 level of convergence). Where milk samples showed convergence problems or bias in the estimation, the procedure was modified according to Stocco et al. (2018b): $\mathrm{CF}_{\mathrm{P}}$ was obtained by multiplying the $\mathrm{CF}_{\max }$ measured during the 
60-min test by the regression coefficient between $\mathrm{CF}_{\mathrm{P}}$ and $\mathrm{CF}_{\max }$ of the non-problematic milk samples of the same dairy species. The other $3 \mathrm{CF}_{\mathrm{t}}$ model parameters $\left(\mathrm{RCT}_{\mathrm{eq}}, \mathrm{k}_{\mathrm{CF}}\right.$, and $\left.\mathrm{k}_{\mathrm{SR}}\right)$ were estimated using the same nonlinear regression as that used for estimating the 4 equation parameters of the other milk samples.

A preliminary statistical analysis showed a small or null effect of the lactodynamographs and their individual pendula, so these effects were not included in the final analysis models. Experimental data from traditional and modeled milk coagulation properties (2 rep- licates per milk sample) of the 5 dairy species (donkey milk samples were excluded) whose milk coagulated within $60 \mathrm{~min}$ of rennet addition were analyzed using the MIXED procedure of SAS, according to the following base mixed model:

$$
\mathrm{y}_{\mathrm{ijk}}=\mu+\text { Species }_{\mathrm{i}}+\text { Sample }(\text { Species })_{\mathrm{i}: \mathrm{j}}+\mathrm{e}_{\mathrm{ijk}},
$$

where $\mathrm{y}_{\mathrm{ijk}}$ is the trait with 2 replicates per milk sample $\left(\mathrm{RCT}, \mathrm{k}_{20}, \mathrm{a}_{30}, \mathrm{a}_{45}, \mathrm{a}_{60}, \mathrm{RCT}_{\mathrm{eq}}, \mathrm{CF}_{\mathrm{P}}, \mathrm{k}_{\mathrm{CF}}, \mathrm{k}_{\mathrm{SR}}, \mathrm{CF}_{\max }\right.$, $\left.t_{\max }\right) ; \mu$ is the overall intercept of the model; Species is $_{\mathrm{i}}$

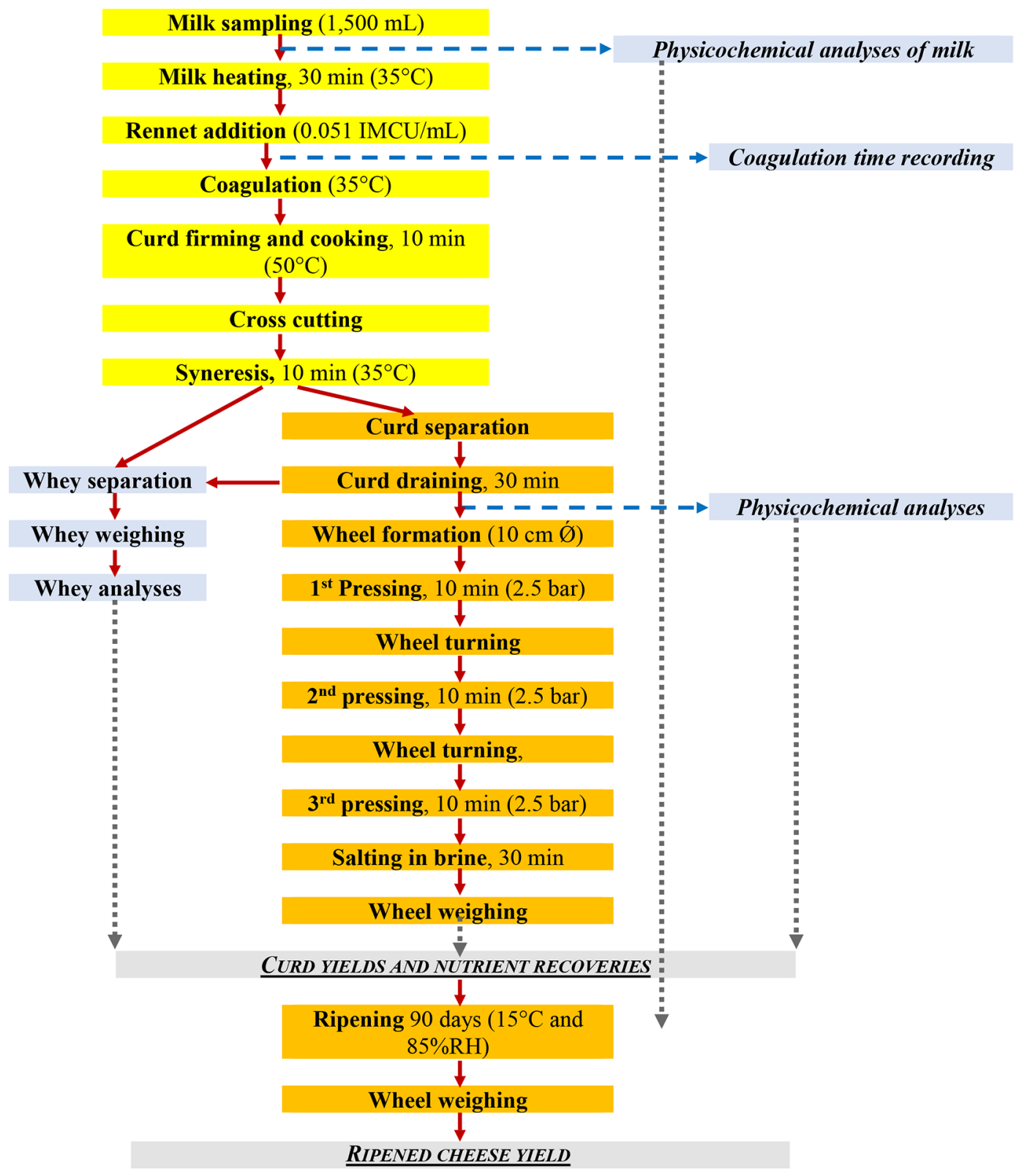

Figure 2. Schematic representation of the procedure adopted for model cheese-making using milk from the 6 major dairy species. IMCU = international milk clotting units; $\mathrm{RH}=$ relative humidity; $\varnothing=$ diameter. 
the effect of the ith dairy species ( $\mathrm{i}=5$ levels, donkey milk samples excluded); Sample(Species) $)_{\mathrm{i}: \mathrm{j}}$ is the random effect of the jth sample within the ith species and is considered to be normally distributed $(\mathrm{j}=1-51) ; \mathrm{e}_{\mathrm{ijk}}$ is the random residual $\sim N\left(0, \sigma_{e}^{2}\right)$ that quantifies the variability between the 2 replicates of each milk sample. In a first analysis, the Species $_{i}$ effect was treated as a random effect to obtain the variance components of species, samples, and residuals, and their relative proportions; in a subsequent analysis, it was treated as a fixed effect to obtain the least squares means (LSM) of the 5 species. The significance of the differences between the LSM of the 5 species was tested using the random effect of sample within species as the error line.

The traits with only 1 analytical value per milk sample (milk solids, fat, protein, casein, casein/protein ratio, lactose, ash, energy, $\mathrm{pH}, \mathrm{SCS}, \% \mathrm{CY}_{\mathrm{CURD}}$, $\% \mathrm{CY}_{\text {SOLIDS }}, \% \mathrm{CY}_{\text {WATER }}, \% \mathrm{CY}_{\text {CHEESE }}, \mathrm{REC}_{\text {PROTEIN }}$, $\mathrm{REC}_{\mathrm{FAT}}, \mathrm{REC}_{\mathrm{SOLIDS}}$, and $\mathrm{REC}_{\text {ENERGY }}$ ) were analyzed using the same models but without the random effect of milk sample (reduced model). All 6 species were compared for milk chemical composition, and the 5 coagulating species (donkey excluded) for cheese-making traits; the significance of the differences between their LSM was tested using the residual as the error line.

Orthogonal contrasts between the LSM of the species were estimated considering their evolutionary taxonomic pathways (illustrated in Figure 1):

(a) Within the Mammalia class, the Perissodactyla order (donkey, monogastrics) vs. the Artiodactyla order (the other 5 species, ruminants and pseudoruminants);

(b) Within the Artiodactyla order, the Camelidae family (dromedary camels, pseudoruminants) vs. the Bovidae family (ruminants);

(c) Within the Bovidae family, the Bovinae subfamily (large ruminants: cattle and buffaloes) vs. the Caprinae subfamily (small ruminants: goats and sheep);

(d) Within the Bovinae subfamily, cows vs. buffaloes;

(e) Within the Caprinae subfamily, goats vs. ewes.

\section{RESULTS}

\section{Descriptive Statistics and Main Sources of Variation of Milk Composition and Cheese-Making Traits}

Descriptive statistics of the chemical compositions, traditional single-point coagulation properties, curd firming modeling $\left(\mathrm{CF}_{\mathrm{t}}\right)$ equation parameters, milk nutrient recoveries in the curd, and cheese-yield traits of the milk samples obtained from the 6 major dairy species are summarized in Table 2. The distribution of the raw data showed significant skew or kurtosis for several milk traits, whereas the residuals obtained from the mixed models used to analyze the data were normally distributed, meaning that the distribution abnormalities were due to the fixed effect of some species.

The proportions of the main variances (species, milk sample within species, and replicates within milk sample or residual variance) of the single-point and modeled milk coagulation property traits analyzed in duplicate are illustrated in Figure 3. As can be seen, the effect of species explained $51 \%$ to $83 \%$ of the phenotypic variance in all the coagulation traits, and the effect of sample within species was responsible for most of the remaining variance. The modest incidence of residual variance is a confirmation of the high repeatability (93-99\%) of direct lactodynamographic measures and of parameters of the $\mathrm{CF}_{\mathrm{t}}$ model, $\mathrm{CF}_{\mathrm{P}}$ excluded (87\%). Figure 4 illustrates the proportions of the variances in traits measured only once per milk sample: chemical composition, nutrient recoveries in the curd, and cheese-yield traits. In this case, the effects of milk sample (different farms, dates, groups of animals, and more) and residual (sampling and analytical variability) are combined. As the graph shows, the effect of species explained more than $86 \%$ of phenotypic variance for milk composition and cheese yield traits, except for lactose, where it explained $70 \%$, and ranged from 58 to $93 \%$ for nutrient recoveries in the curd. Note that the traits with the lowest species variances, lactose and REC traits, are those with the lowest overall coefficient of variation (Table 2). In the case of cheese-yield traits, species represented about $90 \%$ of total variance.

\section{Effects of Dairy Species on Milk Composition}

The LSM of the fixed effects of dairy species on the chemical compositions of the milk samples, reported in Table 3, show large differences among the species compared. The orthogonal contrasts, built reflecting the evolutionary taxonomy of the species compared, were in large measure statistically significant. Note that, for all composition traits, the most significant difference is that between the milk from animals of the Perissodactyla order (donkey species, monogastric) and the Artiodactyla order (5 species, ruminants and pseudoruminants). Within these latter species, all contrasts were significant for the major milk components (solids, fat, protein, casein, lactose, and ash) and for energy content. The major differences, however, were not between the different families and subfamilies, but within the subfamilies. Within the Bovinae, cow milk had much 
lower contents of the major milk components than buffalo milk, and within the Caprinae, the contents were lower in goat than in ewe milk. The contrasts within the Artiodactyla order were generally not significant for the other milk traits, with a few exceptions: the casein/protein ratio and $\mathrm{pH}$ were lower in Camelidae milk than in the 4 species of Bovidae; and the 2 species of Bovinae (cows and buffaloes) had lower SCS and higher $\mathrm{pH}$ compared with the 2 species of Caprinae (goats and sheep).

\section{Effects of Dairy Species on Milk Coagulation Properties}

We observed a large variability in the patterns of coagulation and curd firming over time, both between different species and between milk samples from different farms within species, as the graphs in Figure 5 illustrate. It should be mentioned that none of the milk samples from the only monogastric species investigated (donkey) coagulated within the 60-min time limit.

Table 2. Descriptive statistics of the chemical compositions, traditional single-point coagulation properties, curd firming over time $\left(\mathrm{CF}_{t}\right)$ equation parameters and derived traits, milk nutrient recoveries in the curd (REC), and cheese yields (\% CY) of the milk sampled from the 6 major dairy species

\begin{tabular}{|c|c|c|c|c|c|c|}
\hline Trait & $\mathrm{N}$ & Mean & $\mathrm{SD}$ & $\mathrm{CV}, \%$ & Minimum & Maximum \\
\hline \multicolumn{7}{|c|}{ Milk chemical composition } \\
\hline Total solids, \% & 63 & 13.04 & 3.54 & 27.2 & 7.46 & 19.27 \\
\hline Fat, $\%$ & 64 & 3.99 & 2.53 & 63.3 & 0.10 & 8.54 \\
\hline Protein, \% & 63 & 3.29 & 1.24 & 37.6 & 1.19 & 5.95 \\
\hline Casein, \% & 62 & 2.48 & 1.17 & 47.1 & 0.38 & 4.57 \\
\hline Casein/protein, \% & 63 & 72.34 & 13.73 & 19.0 & 37.90 & 87.73 \\
\hline Lactose, \% & 63 & 4.76 & 0.61 & 12.9 & 3.67 & 6.20 \\
\hline Ash, \% & 62 & 0.70 & 0.20 & 28.5 & 0.21 & 0.93 \\
\hline Energy, $\mathrm{MJ} / \mathrm{kg}$ & 64 & 3.12 & 1.23 & 39.4 & 1.22 & 5.28 \\
\hline $\mathrm{pH}$ & 63 & 6.67 & 0.26 & 3.8 & 6.29 & 7.22 \\
\hline $\mathrm{SCS}^{1}$ & 64 & 4.06 & 2.84 & 70.1 & -2.64 & 8.41 \\
\hline \multicolumn{7}{|c|}{ Coagulation properties $^{2}$} \\
\hline $\mathrm{RCT}, \min$ & 101 & 16.99 & 8.70 & 51.2 & 1.45 & 39.30 \\
\hline $\mathrm{k}_{20}, \min$ & 87 & 5.04 & 5.17 & 102.6 & 1.30 & 37.15 \\
\hline $\mathrm{a}_{30}, \mathrm{~mm}$ & 100 & 26.39 & 17.82 & 67.5 & 0.00 & 74.94 \\
\hline $\mathrm{a}_{45}, \mathrm{~mm}$ & 99 & 26.60 & 14.94 & 56.2 & 2.50 & 70.32 \\
\hline $\mathrm{a}_{60}, \mathrm{~mm}$ & 99 & 24.80 & 15.80 & 63.7 & 0.00 & 72.56 \\
\hline \multicolumn{7}{|l|}{$\mathrm{CF}_{\mathrm{t}}$ parameters ${ }^{3}$} \\
\hline $\mathrm{RCT}_{\mathrm{eq}}, \min$ & 101 & 17.69 & 8.43 & 47.7 & 2.69 & 39.00 \\
\hline $\mathrm{k}_{\mathrm{CF}}, \%$ per min & 101 & 18.92 & 11.90 & 62.9 & 3.30 & 57.53 \\
\hline $\mathrm{k}_{\mathrm{SR}}, \%$ per min & 99 & 1.73 & 1.58 & 91.3 & 0.00 & 5.95 \\
\hline $\mathrm{CF}_{\mathrm{P}}, \mathrm{mm}$ & 100 & 46.43 & 14.36 & 30.9 & 7.36 & 82.86 \\
\hline $\mathrm{CF}_{\max }, \mathrm{mm}$ & 100 & 37.57 & 14.42 & 38.4 & 4.20 & 72.56 \\
\hline $\mathrm{t}_{\max }, \min$ & 101 & 34.88 & 15.00 & 43.0 & 7.75 & 60.00 \\
\hline \multicolumn{7}{|l|}{ Nutrient recovery $^{4}$} \\
\hline $\mathrm{REC}_{\mathrm{FAT}}, \%$ & 61 & 78.13 & 12.87 & 16.5 & 42.08 & 90.78 \\
\hline REC $_{\text {PROTEIN }}, \%$ & 62 & 79.04 & 3.87 & 4.9 & 67.57 & 89.80 \\
\hline $\mathrm{REC}_{\text {SOLIDS }}, \%$ & 62 & 59.46 & 8.33 & 14.0 & 36.15 & 78.52 \\
\hline $\mathrm{REC}_{\text {ENERGY }}, \%$ & 61 & 68.35 & 9.15 & 13.4 & 43.33 & 79.07 \\
\hline \multicolumn{7}{|l|}{ Cheese yields ${ }^{5}$} \\
\hline$\% \mathrm{CY}_{\mathrm{CURD}}, \%$ & 61 & 19.08 & 5.83 & 30.6 & 9.31 & 27.72 \\
\hline$\% \mathrm{CY}_{\text {SOLIDS }}, \%$ & 61 & 9.04 & 2.50 & 27.6 & 3.97 & 12.71 \\
\hline$\% \mathrm{CY}_{\text {WATER }}, \%$ & 61 & 9.67 & 3.38 & 34.9 & 3.26 & 14.35 \\
\hline$\% \mathrm{CY}_{\text {CHEESE-90d }}, \%$ & 62 & 12.01 & 3.90 & 32.5 & 5.16 & 19.12 \\
\hline
\end{tabular}

${ }^{1} \mathrm{SCS}=3+\log _{2}(\mathrm{SCC} / 100,000)$.

${ }^{2} \mathrm{RCT}=$ rennet coagulation time; $\mathrm{k}_{20}=$ time interval between gelation and attainment of curd firmness of 20 $\mathrm{mm} ; \mathrm{a}_{30}\left(\mathrm{a}_{45}, \mathrm{a}_{60}\right)=$ curd firmness after $30(45,60)$ min from rennet addition.

${ }^{3} \mathrm{RCT}_{\text {eq }}=\mathrm{RCT}$ estimated according to curd firmness change over time modeling $\left(\mathrm{CF}_{\mathrm{t}}\right) ; \mathrm{k}_{\mathrm{CF}}=$ curd-firming instant rate constant; $\mathrm{k}_{\mathrm{SR}}=$ syneresis instant rate constant; $\mathrm{CF}_{\mathrm{P}}=$ asymptotic potential curd firmness; $\mathrm{CF}_{\max }$ $=$ maximum curd firmness achieved within 60 min; $\mathrm{t}_{\max }=$ time at achievement of $\mathrm{CF}_{\max }$.

${ }^{4} \mathrm{REC}_{\mathrm{FAT}}, \mathrm{REC}_{\mathrm{PROTEIN}}, \mathrm{REC}_{\mathrm{SOLIDS}}$, and $\mathrm{REC}_{\text {ENERGY}}$ : nutrient (fat, protein, total solids, and energy, respectively) contained in curd as percentage of the corresponding nutrient contained in processed milk.

${ }^{5} \% \mathrm{CY}_{\mathrm{CURD}}, \% \mathrm{CY}_{\text {SOLIDS }}, \% \mathrm{CY}_{\text {WATER}}, \% \mathrm{CY}_{\text {CHEESE-90d }}$ : cheese-yield traits, expressed as weight of the curd, curd total solids, water retained in curd, and fresh cheese after 90-d ripening, respectively, in percentage of the weight of processed milk. 


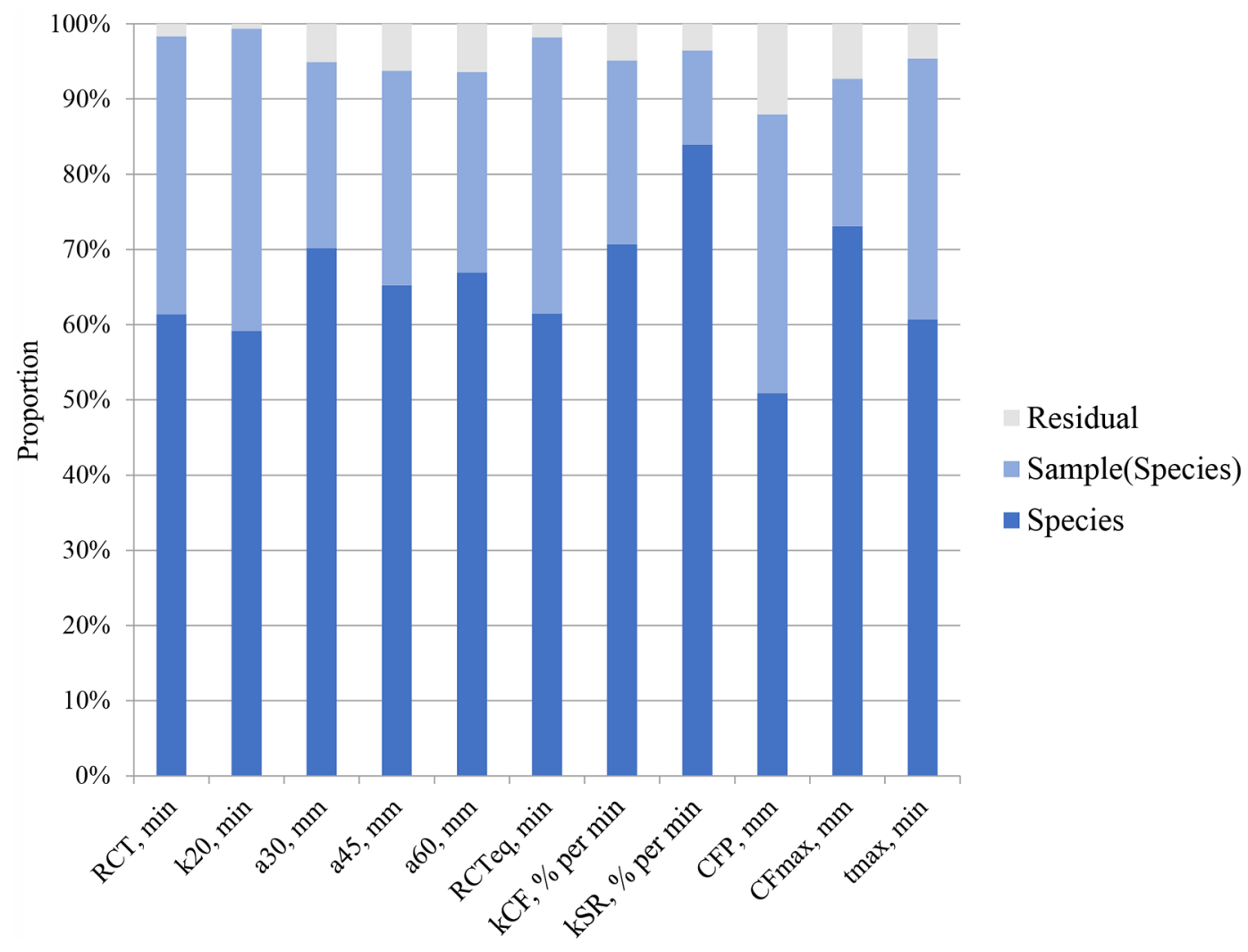

Figure 3. Relative proportions of the variances due to species, milk sample within species, and replicates or residuals within milk samples for

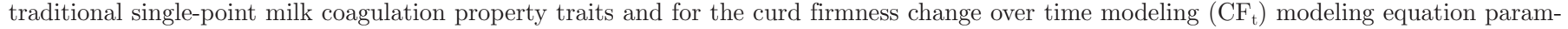
eters and derived traits, analyzed in duplicate. RCT = measured rennet coagulation time; $\mathrm{k}_{20}=$ time interval between gelation and attainment of curd firmness of $20 \mathrm{~mm} ; \mathrm{a}_{30}\left(\mathrm{a}_{45}, \mathrm{a}_{60}\right)=$ curd firmness after $30(45,60)$ min from rennet addition; $\mathrm{RCT}_{\mathrm{eq}}=\mathrm{RCT}_{\mathrm{estimated}}$ according to $\mathrm{CF}_{\mathrm{t}}$; $\mathrm{k}_{\mathrm{CF}}=$ curd-firming instant rate constant; $\mathrm{k}_{\mathrm{SR}}=$ syneresis instant rate constant; $\mathrm{CF}_{\mathrm{P}}=$ asymptotic potential curd firmness; $\mathrm{CF}_{\max }=$ maximum curd firmness achieved within $60 \mathrm{~min} ; \mathrm{t}_{\max }=$ time at achievement of $\mathrm{CF}_{\max }$.

The LSM of the 5 dairy species exhibiting milk coagulation, curd firming, and syneresis, and the significance levels of the orthogonal contrasts between them for the traditional single-point coagulation properties are summarized in Table 4. Regarding the species belonging to the Artiodactyla order, the dromedary camel milk samples (Camelidae, pseudoruminants) did not differ from the average of the 4 species of Bovidae in coagulation time. Among the Bovidae, the milk samples of the 2 large ruminants coagulated more slowly than the milk from the small ruminants, due in particular to bovine milk having a much longer RCT than bubaline milk (29.7 vs. $13.3 \mathrm{~min}$ ). Ovine and caprine milk, however, had similar RCT values (14.2 vs. $12.0 \mathrm{~min}$ ).

Dromedary milk had a longer $\mathrm{k}_{20}$ and smaller $\mathrm{a}_{30}, \mathrm{a}_{45}$, and $\mathrm{a}_{60}$ than the average of the 4 ruminant species. The $\mathrm{k}_{20}$ of the milk from the large ruminants was longer than that of the small ruminants, again due to a large difference within the former. In the case of $\mathrm{a}_{30}$, the 2 subfamilies did not differ from each other, but a large difference was detectable between the 2 large ruminant species (in favor of bubaline milk). Finally, in the case of $\mathrm{a}_{45}$ and $\mathrm{a}_{60}$, differences were apparent between the large and small ruminants, and within the former, as well as a large difference within the latter (smaller in caprine than in ovine milk).

\section{Effects of Dairy Species on Modeled Curd-Firming and Syneresis Patterns}

Despite the large variability among the different milk samples (different farms and sampling dates), each species presented a typical pattern of curd firmness over time (Figure 5); this affects the LSM of the parameters of the $\mathrm{CF}_{\mathrm{t}}$ model equation and the traits of the dairy species, as well as the significance levels of their orthogonal contrasts (summarized in Table 4). The averages of the $2 \mathrm{RCT}$ ( $\mathrm{RCT}$ and $\mathrm{RCT}_{\text {eq }}$ ) values were very similar to each other (and differed from species to species), as were the significance levels of the comparisons between the various species, with the exception of dromedary milk compared with the milk from the 4 


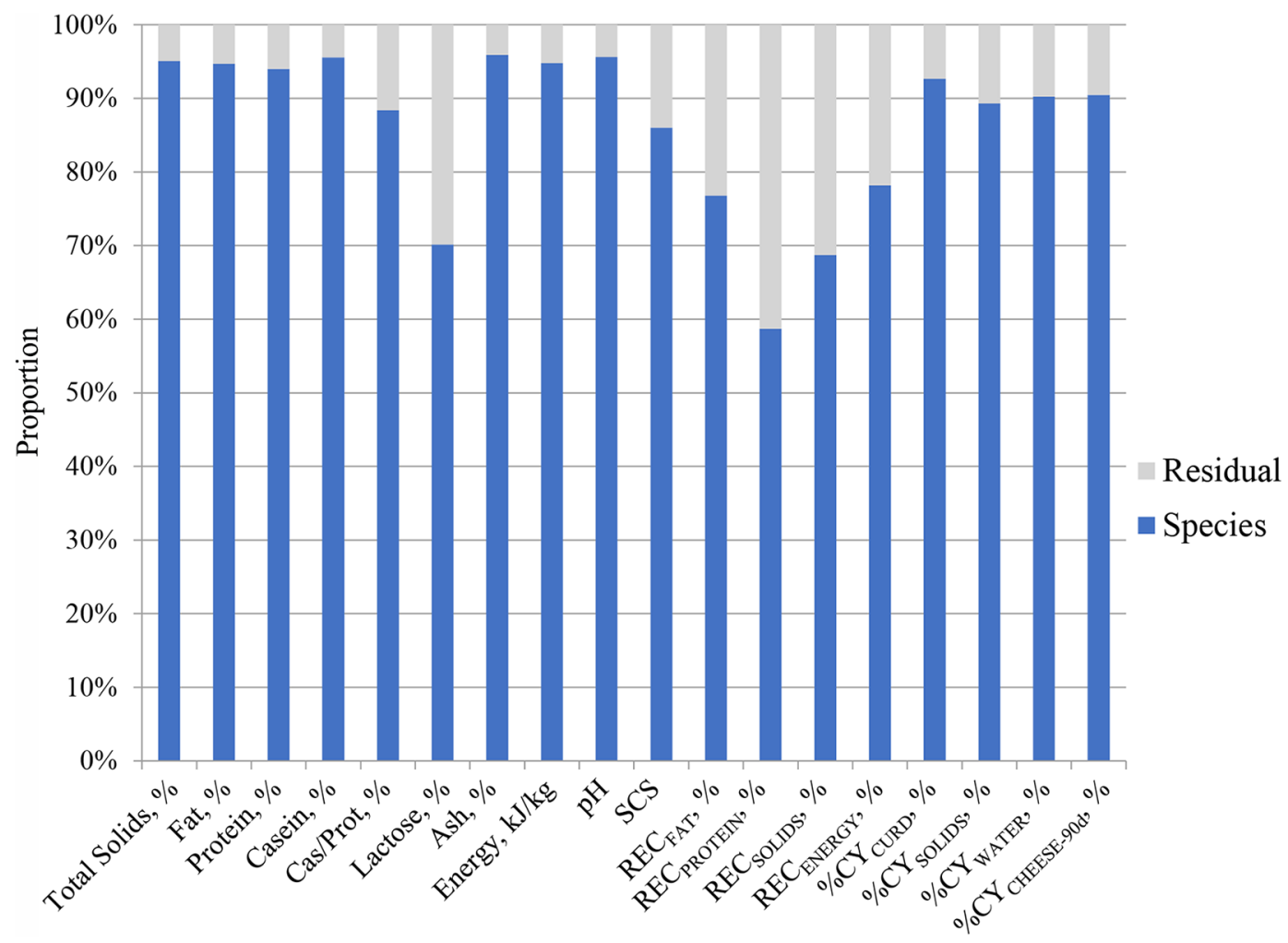

Figure 4. Relative proportions of the variances due to species and milk sample within species or residuals for milk composition, nutrient recovery in the curd, and cheese-yield traits, analyzed once per milk sample. Cas/Prot $=$ ratio of casein to protein; $\mathrm{REC}_{\mathrm{FAT}}, \mathrm{REC}_{\mathrm{PROTEIN}}$, $\mathrm{REC}_{\text {SOLIDS}}$, and $\mathrm{REC}_{\mathrm{ENERGY}}=$ nutrient (fat, protein, total solids, and energy, respectively) contained in curd as percentage of the corresponding nutrient contained in processed milk; $\% \mathrm{CY}_{\mathrm{CURD}}, \% \mathrm{CY}_{\mathrm{SOLIDS}}, \% \mathrm{CY}_{\mathrm{WATER}}, \% \mathrm{CY}_{\mathrm{CHEESE}-90 \mathrm{~d}}=$ cheese-yield traits expressed as weight of the curd, curd total solids, water retained in curd, and fresh cheese after 90-d ripening, respectively, in percentage of the weight of processed milk.

ruminant species, which did not reach the significance threshold in the case of RCT, but was below it in the case of $\mathrm{RCT}_{\text {eq }}$.

The curd-firming instant rate constant $\left(\mathrm{k}_{\mathrm{CF}}\right)$ was slower in the Camelidae than in the Bovidae family and in the Bovinae than in the Caprinae subfamily, and within the subfamilies it was slower in bovine compared with bubaline milk and in caprine compared with ovine milk. The syneresis instant rate constant $\left(\mathrm{k}_{\mathrm{SR}}\right)$ was the same in the Camelidae and Bovidae families but differed greatly between the Bovinae and Caprinae subfamilies (in favor of the latter), and within the Caprinae subfamily between goats and ewes (in favor of the former).

Both the $\mathrm{CF}_{\mathrm{P}}$ asymptotical value and the $\mathrm{CF}_{\max }$ were smaller for camel milk than for ruminant milk but similar for large and small ruminants. However, they were larger in buffalo and ewe milk compared with cow and goat milk. The time to $\mathrm{CF}_{\max }\left(\mathrm{t}_{\max }\right)$ was similar between Camelidae and Bovidae families but longer in large ruminants compared with small ones, because of the longer time taken by bovine milk samples.

\section{Effects of Dairy Species on the Recovery of Milk Nutrients in the Curd}

The LSM of the fixed effect of dairy species and the levels of significance of the orthogonal contrasts of the recovery coefficients of milk nutrients retained in the curd are shown in Table 5. Nutrient recovery was affected by dairy species: it was null for donkey milk, as it does not coagulate at all, and regarding the other species, $\mathrm{REC}_{\mathrm{FAT}}$ was modest in dromedary milk, and was greater for large ruminants than for small ruminants. Among the large ruminants, $\mathrm{REC}_{\mathrm{FAT}}$ was greater in bubaline than in bovine milk, and among the small ruminants the difference was not significant.

The $\mathrm{REC}_{\text {PRotein }}$ presented much smaller differences among species (donkey excluded); the average value was slightly lower for dromedary milk than for ruminant milk, whereas among the ruminants, it was higher for large ruminants, especially bovine milk, than for small ruminants. The $\mathrm{REC}_{\text {SOLIDS }}$ and $\mathrm{REC}_{\text {ENERGY }}$ were much more influenced by $\mathrm{REC}_{\mathrm{FAT}}$ than by $\mathrm{REC}_{\mathrm{PROTEIN}}$; the statistical analysis therefore showed dromedary 


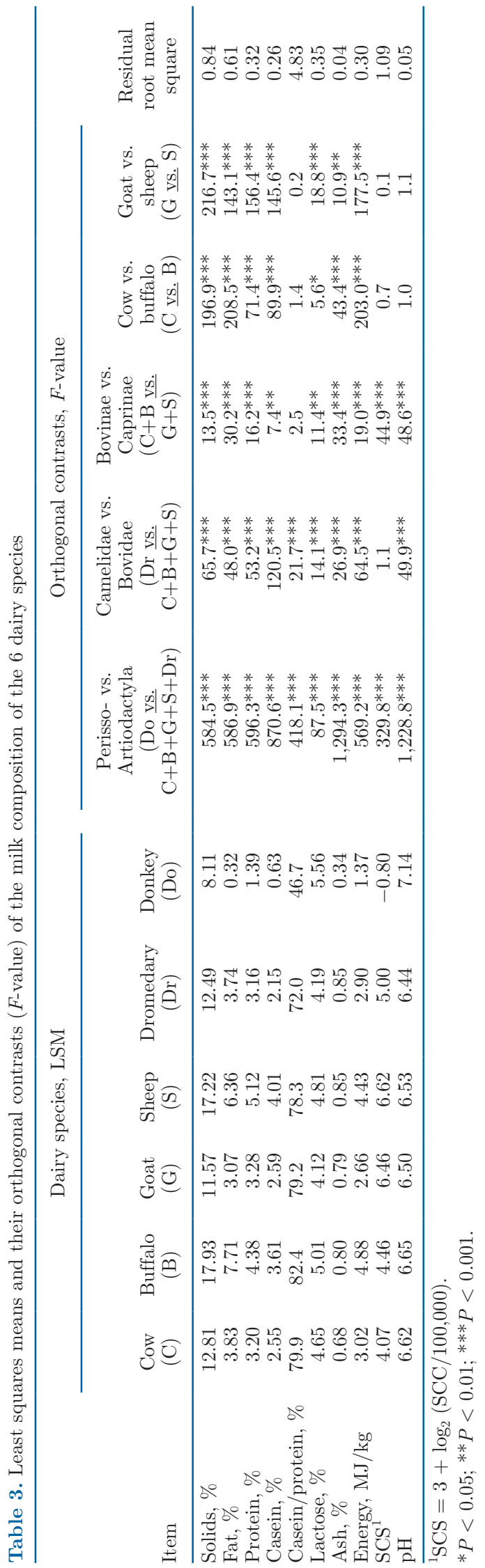

milk to be inferior to ruminant milk, small ruminants inferior to large ruminants, and cows and goats inferior to buffaloes and ewes (only for $\mathrm{REC}_{\text {ENERGY }}$ ).

\section{Effects of Dairy Species on Cheese-Yield Traits}

The LSM of the fixed effect of dairy species and the significance levels of their orthogonal contrasts of cheese-yield traits are summarized in Table 5. The various dairy species presented very large differences in cheese yield, which encompasses milk composition, coagulation, curd-firming and syneresis patterns, and milk nutrient recoveries in the curd. For all the cheese-yield traits, dromedary milk was inferior to the average of the milk from the 4 ruminant species, small ruminants were slightly inferior to large ruminants, and, within subfamilies, bovine and caprine milks were inferior to bubaline and ovine milks.

\section{DISCUSSION}

In this section we will discuss the results for each non-bovine dairy species and make some comparisons with bovines, which are taken as the reference. To reduce variability due to individual animals and to obtain results representative of a variety of farms, we used bulk milk samples from different farms, with the only exception of dromedary milk (milk samples from free-ranging females in 2 different grazing areas). Obviously, the results obtained reflect the prevalent climatic conditions, farming and feeding systems, and prevalent breeds of the sampled areas, as summarized in Table 1.

\section{Composition and Cheese-Making Ability of Donkey Milk}

Equine milk from both mares and donkeys is traditionally consumed in some areas of the world, especially the steppes of Central Asia, although it is gaining attention worldwide because of its composition. Our results confirm donkey milk as very different from the milk of Artiodactyla dairy species: the low fat and protein contents and high lactose content make it more similar than ruminant milk to human milk (Salimei, 2011; Salimei and Fantuz, 2012). Not only does it have less than half the protein content of other species, its composition is also very different, being characterized by much less casein and more whey proteins (Vincenzetti et al., 2008; Salimei, 2011). It should be mentioned that the analytical methods used can affect or bias the results (Oftedal and Iverson, 1995). The method most frequently used for analyzing milk, Fourier-transform infrared spectrometry, is not calibrated nor validated for equine milk, and using calibrations developed for 
milk from dairy cows or other ruminants can give rise to biased results (G. Bittante unpublished data, University of Padova, Padua, Italy). Moreover, the refer- ence methods for determining milk casein content are based on the use of bovine rennet (Ribadeau-Dumas and Grappin, 1989), which is not specific for the casein
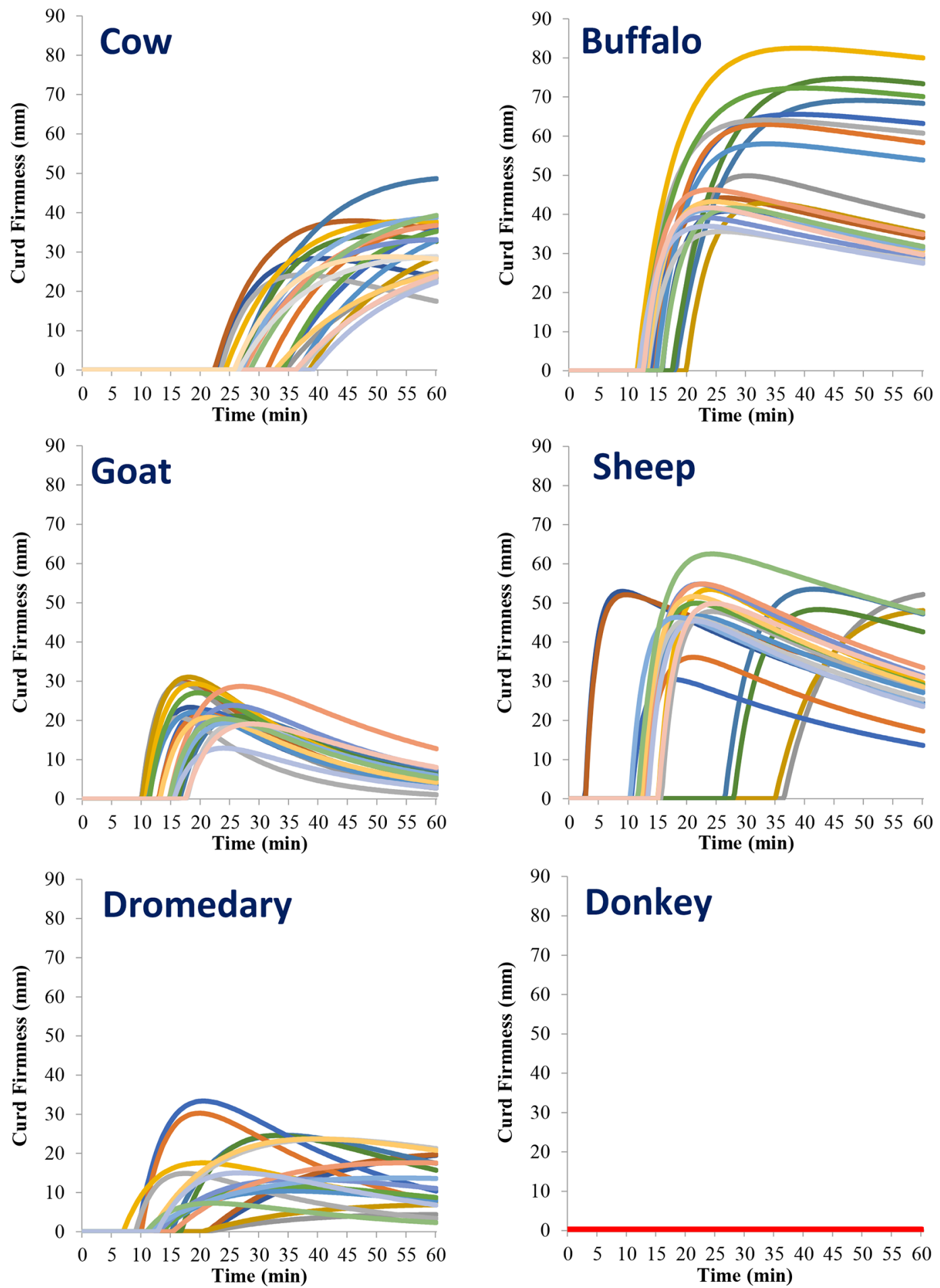

Figure 5. Plots of the modeled equations obtained from the 240 single-point curd firmness observations recorded over 60 min $(1$ every 15 s) for each milk sample replicate, grouped according to dairy species, showing the patterns of each species and the within-species variability. 
Bittante et al.: CHEESE-MAKING WITH MILK FROM DIFFERENT SPECIES

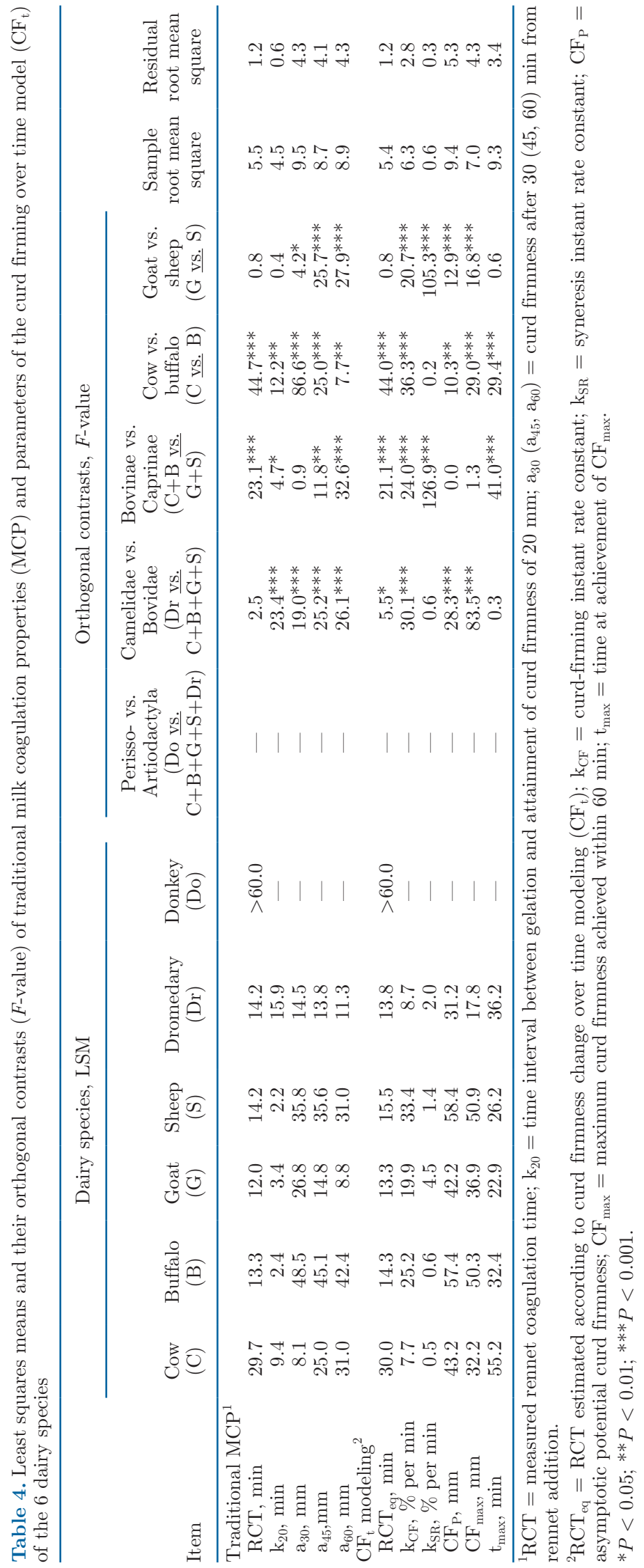




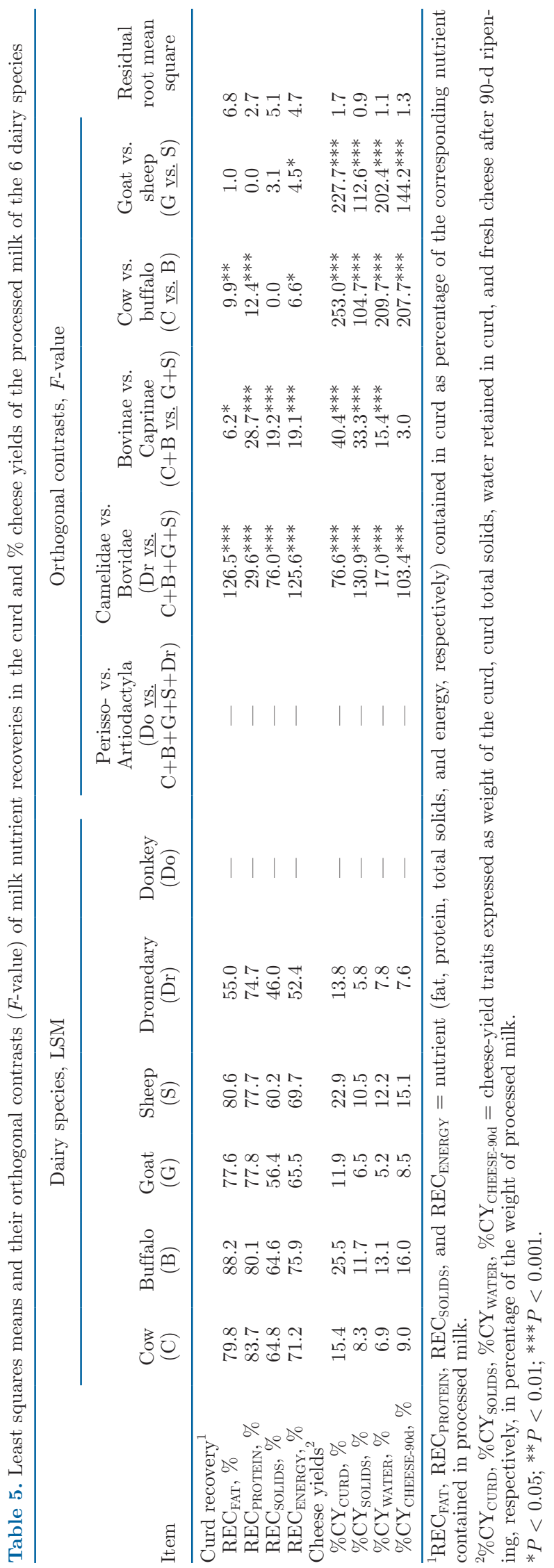

fractions of equine milk, and the methods for separating different casein and whey proteins have not been optimized and validated for equine milk.

The low content of protein, especially casein, and possible differences in the types of protein fractions, their characteristics and genetic variants on one side, and the use of bovine rennet with unknown affinity for equine milk on the other, could account for the absence of milk gelation, curd firming, and syneresis in donkey milk. It is worth mentioning that other authors (Doreau and Martin-Rosset, 2011) have also observed little or no coagulation of equine milk, as reviewed by Faccia et al. (2018). Iannella (2015) obtained a curd from donkey milk only by using a procedure very different from those commonly used in commercial cheese production: the milk was not heat-treated, and the temperature was maintained at $37^{\circ} \mathrm{C}$; thermophilic starter culture was added; after 90 min camel chymosin was added; and the curd was separated after $5 \mathrm{~h}$. The average curd yield was as low as $3.3 \%$ of the milk processed, and the dry matter content was $35.7 \%$, which means that the curd solids obtained represented only $1.18 \%$ of the milk processed. Other authors have used vegetal (Sampaio, 2017) or microbial (Faccia et al., 2020b) rennet and other adjuvants (D'Alessandro et al., 2019).

Although donkey milk is unsuitable for cheese-making, and despite its low fat and protein contents, it is nonetheless gaining interest in human nutrition, as it has other valuable nutritional characteristics. Particularly attractive is its similarity to human milk, which favors its use with infants and also preterm babies (Monti et al., 2007; Martini et al., 2018; Bertino et al., 2019). Recent studies claim that the propensity of donkey milk to provoke digestive intolerance in children is low (Murgia et al., 2016; Souroullas et al., 2018). Moreover, because equines are monogastric, donkey milk does not contain phytanic acid, which is produced from chlorophyll in the rumen, so it is suitable for individuals with Refsum disease (Wanders et al., 2011; Devle et al., 2012; Roca-Saavedra et al., 2017). Further studies are needed to characterize in greater detail the chemical composition of donkey (and mare) milk, to study its coagulation behavior in the human stomach and intestine, and to evaluate its effects on the health of infants, children, and adults.

\section{Composition and Cheese-Making Ability of Dromedary Camel Milk}

Camelid milk is an essential provider of high-quality nutrients to humans in very arid environments (Alhadrami, 2011; Sakandar et al. 2018). Few studies have been conducted on the production of cheese from camel milk (Ramet, 2001), and even fewer have compared the re- 
sults with milk from ruminants. In this study, we found that dromedary milk, like goats' milk, was similar in composition to bovine milk, confirming the results reviewed by Medhammar et al. (2012).

Although the composition of camel milk is similar to cow milk, the coagulation, curd-firming, and syneresis patterns are profoundly different, as observed by Bornaz et al. (2009) and Qadeer et al. (2019) and as reviewed by Faccia et al. (2020a). The orthogonal contrasts based on evolutionary taxonomy, which clearly separates the Camelidae order from the Bovidae order (Figure 1), revealed highly significant differences in almost all the traits related to the cheese-making aptitude of milk. The practical meaning of the observed differences in the $\mathrm{CF}_{\mathrm{t}}$ equation parameters among the species is clearly illustrated in Figure 6, which shows the average coagulation, curd-firming, and syneresis patterns characterizing the milk of the 6 major dairy species on the basis of the LSM values of their equation parameters. The graphs show clearly that dromedary milk coagulates much earlier than cow milk $\left(\mathrm{RCT}_{\text {eq }}\right)$, and after a similar time interval to the other ruminant species. However, the rising part of the curve $\left(\mathrm{k}_{\mathrm{CF}}\right)$ for dromedary milk is similar in steepness to that of cow milk, and much less steep than the other ruminants. The patterns for both dromedary and cow milk observed here are very similar to those for skim milk observed by Omar et al. (2018): RCT values were almost identical
(29.7 vs. $31.2 \mathrm{~min}$ for whole vs. skimmed cows' milk, and 14.2 vs. 16.2 min for whole vs. skimmed dromedary camel milk). Very different were the results obtained by Bouazizi et al. (2021), who, using dromedary chymosin, obtained with dromedary milk a coagulation much delayed compared with cow milk (72.3 vs. $27.5 \mathrm{~min}$ ). The $\mathrm{k}_{\mathrm{SR}}$ of dromedary milk found in our study is about 3 times greater than that of bovine milk, which explains why the descending phase of the curve (syneresis) begins 36 min after rennet addition, whereas it is not yet clearly distinguishable at the end of the test $(60 \mathrm{~min})$ in the case of cow milk. The greater $k_{\mathrm{SR}}$ also explains why, even though the asymptotical potential curd firmness $\left(\mathrm{CF}_{\mathrm{P}}\right)$ is similar in the 2 species, the $\mathrm{CF}_{\max }$ observed within $60 \mathrm{~min}$ is much lower in camelid milk than in bovine milk. These differences could be related to differences in the proportions of protein fractions, and particularly to the low proportion of the $\kappa$-casein-type fraction in camel milk (Omar et al., 2016), as it is well known that the concentrations and relative proportions of different caseins and whey proteins in milk affect its coagulation properties (Amalfitano et al., 2019) and cheese-yield efficiency (Cipolat-Gotet et al., 2018).

In this study, the milk samples of all species were mixed with the same rennet of bovine origin ( $80 \%$ chymosin and $20 \%$ pepsin). It should be noted that the chymosin enzyme produced by camels gives their milk greater coagulation efficiency compared with bovine

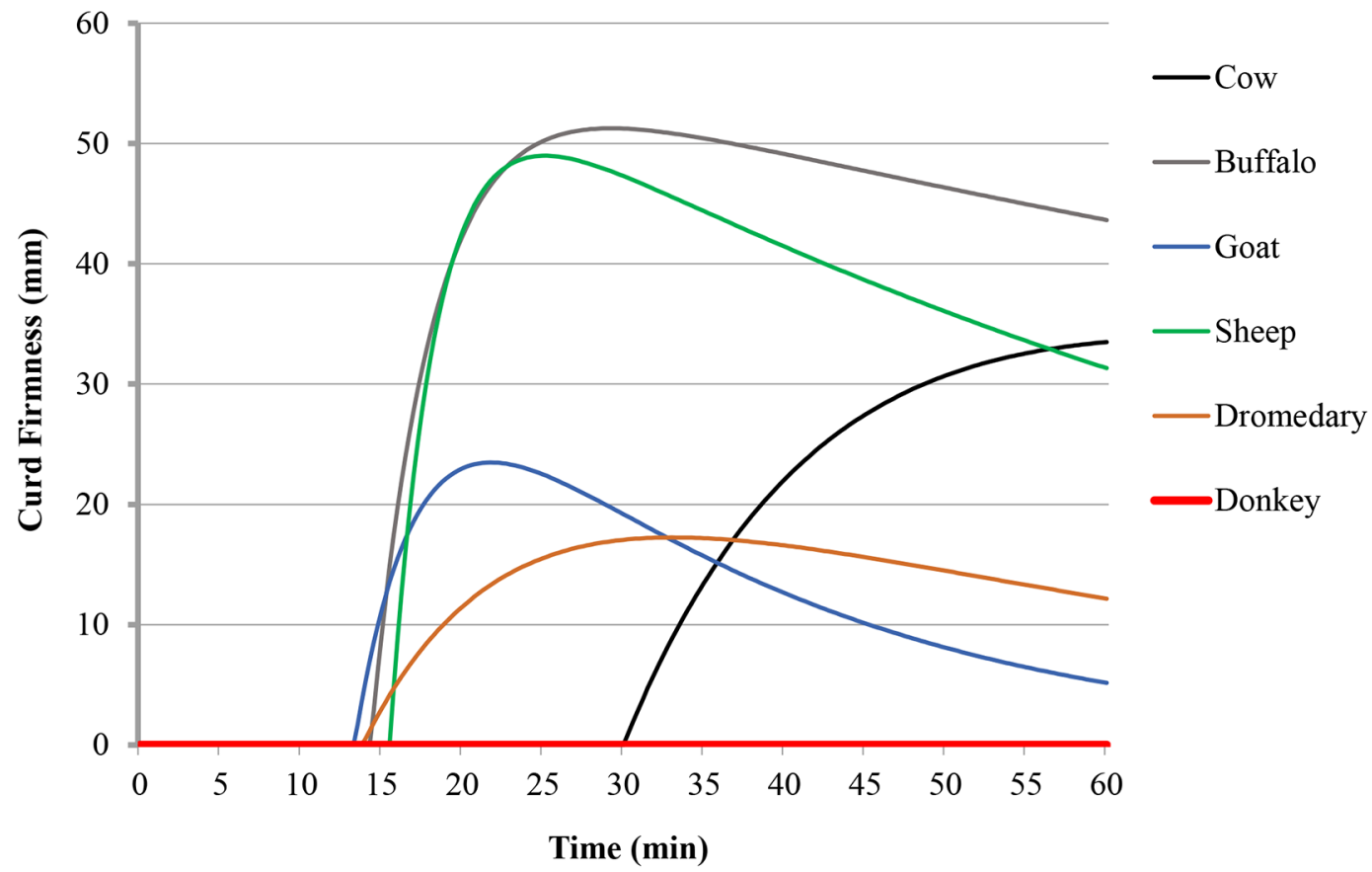

Figure 6. Average modeled pattern of curd firmness over time after rennet addition, obtained using the LSM of the equation parameters of the 6 major dairy species. 
chymosin (Kappeler et al., 2006; Sørensen et al., 2011; Langholm Jensen et al., 2013) and may compensate for the "weakness" of camel curd. Camel chymosin is, in fact, sometimes used in the dairy industry for producing bovine cheeses, especially when coagulation is slow and curd weak.

\section{Composition and Cheese-Making Ability of Sheep Milk}

Sheep milk is used almost exclusively for cheese production, especially in countries of the Mediterranean basin (Fahmy and Shrestha, 2002; Noce et al., 2016), a preference that is clearly related to its excellent cheesemaking ability (Bittante et al., 2014; Leitner et al., 2016). Its rapid coagulation after rennet addition and very fast increase in CF compared with bovine milk is well known (Gelè et al., 2014; Pazzola et al., 2014; Pazzola, 2019). In fact, sheep milk had the highest $\mathrm{k}_{\mathrm{CF}}$ of the different species investigated here. The syneresis instant rate constant was at an intermediate level and similar to dromedary camel milk. A large variability in $\mathrm{k}_{\mathrm{SR}}$ among milk samples of different individual ewes has sometimes been observed. Vacca et al. (2015) found that the $\mathrm{CF}_{\mathrm{t}}$ curve of milk produced by about one-third of ewes had no descending phase, and that the milk also had no estimable $\mathrm{k}_{\mathrm{SR}}$ value. The milk samples in the present study were not obtained from individual ewes within a flock but were rather bulk milk from different flocks, so they represent the average pattern of many ewes from different farms, which can explain why the $\mathrm{CF}_{\mathrm{t}}$ curve of all but one of the sheep milk samples had a clear descending phase.

The REC traits of sheep milk were intermediate with respect to the milk samples from the other ruminants. This, combined with the very high fat, protein, and casein contents, explains the very high cheese-yield traits characterizing ewe milk, which confirms previous results obtained with similar methodologies (Cipolat-Gotet et al., 2016a). Note that other model cheese-making procedures separate the curds and whey through centrifugation, although the separation is not satisfactory with this process (Cipolat-Gotet et al., 2016b) and it leads to overestimation of the cheese yield (Othmane et al. 2002; Manca et al., 2016). This suggests the need for a common methodology to more accurately compare different species, although the drawback would be that it could not be adapted to the specific characteristics of milk from different species.

\section{Composition and Cheese-Making Ability of Goat Milk}

Different breeds of goat present very different milk composition characteristics (Devendra and Haenlein,
2011). The fat and protein contents of milk from goat breeds of Alpine origin, like those sampled in this study, differ little from cow's milk, whereas breeds of Mediterranean origin are characterized by much greater milk nutrient contents (Vacca et al., 2018a), similar to sheep milk. Coagulation and curd-firming abilities are also largely affected by breed (Vacca et al., 2018a; Pazzola, 2019), in part due to differences in the genetic variants of milk protein fractions (Pazzola, 2019). In most cases, goat milk falls between the patterns typical of ovine and bovine milk (Gelè et al., 2014; Leitner et al., 2016). It is worth noting that goat milk exhibited the highest $\mathrm{k}_{\mathrm{SR}}$ instant rate (Table 5), which explains the large difference between $\mathrm{CF}_{\mathrm{P}}$ and $\mathrm{CF}_{\max }$ (the former similar to sheep milk, the latter similar to cow milk; Table 5) and why $\mathrm{CF}_{\max }$ was reached at the earliest $\mathrm{t}_{\max }$ compared with all the other species. A high $\mathrm{k}_{\mathrm{SR}}$ is often interpreted as the result of rapid syneresis expelling the whey from the curd, which can then float freely in the vat, giving less resistance to the pendulum of the lactodynamograph (Bittante et al., 2013). However, in the case of goat milk, fragile curds are frequently obtained (Leitner et al., 2016; Roy et al., 2020), especially in Alpine breeds (Pazzola et al., 2018; Vacca et al., 2018a), which means that the descending phase of the $\mathrm{CF}_{\mathrm{t}}$ curve (and the high $\mathrm{k}_{\mathrm{CF}}$ ) can be interpreted not as the result of increasing syneresis and actual curd firmness but instead as fragmentation caused by the pendulum in the curd (Vacca et al., 2020). This also explains why the milk of Alpine goats is often coagulated by acidification instead of renneting to produce very fresh cheeses (Moatsou and Park, 2017). In any case, it is the differences in milk nutrient contents that are responsible for the substantial differences in the cheese yields of goat and sheep milk (Leitner et al., 2016), and of different goat breeds, especially between those of Alpine and Mediterranean origin (Vacca et al., 2018b; Pazzola et al., 2019).

\section{Composition and Cheese-Making Ability of Buffalo Milk}

The milk produced by buffaloes has the highest content of total solids and fat, and the second-highest protein content (but the greatest casein/protein ratio) of the 6 major dairy species (Table 3; Aspilcueta-Borquis et al., 2010; Roy et al., 2020). The coagulation and curd-firming patterns of the milk of this species are also excellent (Ariota et al., 2007; Cecchinato et al., 2012) and compete with ovine milk for first place (Figure 6 ). Buffalo milk had the highest recoveries in the curd of fat and energy (Table 5), so not only did it have the highest cheese yield (Zicarelli, 2004; Dettori et al., 2009), it also had the highest cheese-making efficiency, 
Table 6. Average daily production of milk, milk energy, ripened cheese, and ripened cheese energy of the 6 major dairy species, expressed per lactating head, per unit of live weight (LW), and per unit of metabolic weight (MW)

\begin{tabular}{|c|c|c|c|c|c|c|}
\hline Item & Cow & Buffalo & Goat & Ewe & Dromedary & Donkey \\
\hline \multicolumn{7}{|l|}{ Milk yield } \\
\hline Per head, $\mathrm{kg} / \mathrm{d}$ & 33 & 8 & 3 & 1.5 & 3 & 2 \\
\hline Per unit of LW, $\mathrm{g} / \mathrm{kg}$ & 51 & 11 & 55 & 36 & 8 & 7 \\
\hline Per unit of $\mathrm{MW}, \mathrm{g} / \mathrm{kg}$ & 256 & 59 & 150 & 91 & 34 & 29 \\
\hline \multicolumn{7}{|l|}{ Milk energy yield } \\
\hline Per head, MJ/d & 100 & 39 & 8 & 7 & 9 & 3 \\
\hline Per unit of $\mathrm{LW}, \mathrm{kJ} / \mathrm{kg}$ & 153 & 56 & 145 & 161 & 22 & 10 \\
\hline Per unit of MW, kJ/kg & 773 & 287 & 399 & 410 & 98 & 40 \\
\hline \multicolumn{7}{|l|}{ Cheese yield } \\
\hline Per head, kg/d & 2.97 & 1.28 & 0.26 & 0.23 & 0.23 & 0.00 \\
\hline Per unit of LW, g/kg & 4.6 & 1.8 & 4.6 & 5.4 & 0.6 & 0.0 \\
\hline Per unit of $\mathrm{MW}, \mathrm{g} / \mathrm{kg}$ & 23.0 & 9.4 & 12.8 & 13.7 & 2.6 & 0.0 \\
\hline \multicolumn{7}{|l|}{ Cheese energy yield } \\
\hline Per head, MJ/d & 71.0 & 29.6 & 5.2 & 4.7 & 4.6 & 0.0 \\
\hline Per unit of LW, $\mathrm{kJ} / \mathrm{kg}$ & 109 & 42 & 95 & 111 & 11 & 0 \\
\hline Per unit of MW, $\mathrm{kJ} / \mathrm{kg}$ & 550 & 218 & 261 & 283 & 51 & 0 \\
\hline
\end{tabular}

retaining as much as $76 \%$ of milk energy in the cheese. In a previous study, using the same model cheesemaking procedure and a large number of individual buffalo milk samples, Cipolat-Gotet et al. (2015) found an average $\mathrm{REC}_{\text {ENERGY }}$ of $79.3 \%$, compared with $67.2 \%$ for bovine milk. Cheese-making efficiency was found to be unaffected by the buffalo's parity, but it increased with advancing stage of lactation.

The fact that the cheese yield in solids of buffalo milk was much larger that of cow milk compensates in part for the much lower daily milk yield of this species compared with cows, and explains why buffalo are the second most important producers of milk in the world (Sun et al., 2014). Buffalo are well suited not only to tropical (hot, humid) environments, where specialized dairy cows have difficulty adapting to the conditions and can develop health problems (Khan, 2002), but also to temperate climates in developed countries (Arora and Khetra, 2017). In Italy, which has the largest dairy buffalo population in Europe, a combination of very high cheese yield and products of excellent quality (i.e., buffalo mozzarella cheese) mean that buffalo milk fetches a price 3 to 4 times higher than cow milk (Addeo et al., 2007).

\section{Cheese Production of the 6 Major Dairy Species}

Direct comparison of the 6 dairy species in terms of daily cheese production and cheese production efficiency is beyond the scope of this study, but some considerations can be made on the basis of the average daily milk yields and live weights of the lactating females in the farms sampled. The variability in milk quality and technological properties due to different farms and animals within species is generally much lower than the variability in daily milk yield (Bittante et al., 2015; Stocco et al., 2018a). However, the differences among the dairy species are so large that some inferences can be drawn, albeit cautiously. The differences in terms of average daily milk yield between the most productive species (cows) and the others ranges from about a quarter (buffalo) to a twentieth (sheep). This is explained firstly by the differences in animal size and, second, by differences in dairy systems. To aid discussion of the differences among the species, in Table 6 we summarize some of the raw ratios obtained from the milk yields and live weights recorded or estimated, and the milk energy contents, ripened cheese yields, and milk energy recoveries in the cheese measured in this study. The daily productions of milk, milk energy, ripened cheese, and cheese energy are expressed per lactating head, per unit of live weight, and per unit of metabolic weight.

If the milk yield is divided by the live weight of the animal (grams of milk per kilogram of live weight) (Table 6), goats produce about the same amount of milk as cows, and sheep produce an amount that is intermediate between cows and buffaloes. The milk production of dromedary camels and donkeys remains in the order of 6 to 7 times lower than cows.

One of the most important determinants of production efficiency is the ratio between the nutrient requirements for milk production and for animal maintenance (Tempelman and Lu, 2020). It seems, however, that a scaling factor based on average metabolic weight (MW $=\mathrm{LW}^{0.75}$, where $\mathrm{LW}=$ live weight) could be more informative, as it would in some way represent production per unit of net energy required for animal maintenance. It should be borne in mind that the concept of MW was first proposed for comparing species of very different sizes (Brody, 1945). Scaled for MW, the bovine 
species remained about 8 to 10 times more productive than the 2 less-productive species, with caprine species intermediate.

However, the differences among the dairy species are, to a large extent, explained by differences in milk composition. The metabolic burden of lactation is first represented by the quantity of energy secreted with milk. The energy content of buffalo milk, the species with the highest net energy content, is 3.5 times that of the species with the lowest net energy content (donkey). Therefore, a need exists for a proxy for milk production efficiency in terms of milk energy, and not only of milk volume, especially when comparing very different species. As can be seen from Table 6, after taking into account the energy content of milk, the superiority of the bovine species over the asinine species increases about 35-fold when milk energy secreted is expressed per head, 16-fold when expressed per unit of LW, and 20-fold when expressed per unit of MW. However, the values for the small ruminants are now similar because the higher energy content of sheep milk tends to compensate for the higher milk production of goats (Table 6). When scaled on LW, the daily milk energy production of small ruminants appears to be comparable to that of cows, whereas scaled on MW, the values for these 2 species are about half that of the bovine species. It worth noting that, although buffaloes differ little in size from cows, their energy production values are about one-third those of bovines, regardless of the scaling factor. The energy output of dromedary camels remained much lower than that of cows (8-12 times), although much larger than that of donkeys.

As this study focuses on the cheese-making ability of different dairy species, we can conclude with some considerations on the daily cheese production of the different species. We can exclude the equine species from this discussion, not only because of their low daily milk production and very low content of coagulating solids (fat and casein) in the milk, but also because of the difficulties in getting the milk to coagulate.

Cheese productivity of the ruminant and pseudoruminant species is more a reflection of the values in terms of milk energy than in terms of milk volume (Tempelman and $\mathrm{Lu}, 2020$ ), given the strong relationships between the energy content of milk and cheese yield per unit of fluid milk. Therefore, the considerations regarding daily milk energy secreted by the different species could also apply to daily cheese production, with the difference that the values for buffaloes and, in part, sheep are slightly greater, and values for dromedary camels are lower due to differences in the milk nutrient recoveries in fresh cheese.

The final consideration, which takes daily milk production, animal size, milk composition, and cheese-making efficiency of different species together, is summarized by the daily production of cheese energy per unit of MW. As can be seen from Table 6, the productivity of cows seems to be 2 times that of small ruminants, 2.5 times that of buffaloes, and 11 times that of dromedary camels. Obviously, these differences are related to the cheese-making procedures used in this study, which are optimized for bovine milk. Cheese-making conditions, especially coagulant type and concentration, have been shown to interact with dairy species (Liburdi et al., 2019). Moreover, the differences observed reflect the genetic specificities of the different species, as well as the animals' different environmental conditions and the different dairy systems. Note that, whereas in Italy cows and buffaloes are mainly raised on intensive dairy farms on the plains, small ruminants are often managed semi-intensively in the hills. In these hilly conditions, cows' productivity is much lower than on the plains, so the daily cheese energy production per unit MW can be expected to be not much different from that of the small ruminants. The productivity of dromedary camels is much lower than the 4 ruminant species, although their environmental conditions are the harshest and management is the most extensive. In these very hot and arid conditions, cows probably could not survive, and small ruminants would have difficulty adapting. Thus, despite their low productivity, dromedary camels can provide humans with a highly nutritious food (milk, dairy products, and meat) in areas where no alternative type of production is sustainable (Zarrin et al., 2020).

Regarding the rearing of dairy species in developed countries, it should be borne in mind that, aside from production efficiency and technological properties, the economics of dairy farms rearing "minor" species is strongly affected by the price paid for the milk in local (niche) markets. In Italy, milk from small ruminants generally fetches a price in the range of 1.5 to 2 times that of cow milk, buffalo milk 2.5 to 3 times, and donkey milk up to 10 times.

\section{CONCLUSIONS}

The 6 major dairy species produce milk with very different compositions and abilities of the milk to coagulate and of the curd to firm and expel whey and to retain milk nutrients. Asinine milk is the most similar to human milk but is not a valuable source of cheese because it does not coagulate and has very low fat and casein contents. Camelid milk, compared with the other species, has a similar coagulation time but a less favorable curd-firming process, with lower nutrient recovery and cheese yield, and requires specific cheese-making conditions and the use of camel chymosin. Bubaline and ovine milks have better cheese-making aptitudes 
(nutrient contents, coagulation and curd firming properties, nutrient recovery in the curd, and cheese yield) compared with bovine and caprine milks. Bovine milk is characterized by a late coagulation and caprine milk by a rapid decrease in curd firmness after attaining the maximum.

\section{ACKNOWLEDGMENTS}

The authors thank the Italian Ministry of Agriculture, Forestry and Food Policies (Rome) for funding the GOOD-MILK project (D.M. 9367185; 09/12/2020). The authors have not stated any conflicts of interest.

\section{REFERENCES}

Addeo, F., V. Alloisio, L. Chianese, and V. Alloisio. 2007. Tradition and innovation in the water buffalo dairy products. Ital. J. Anim. Sci. 6(Suppl. 2):51-57. https://doi.org/10.4081/ijas.2007.s2.51.

Alhadrami, G. A. 2011. Animals that produce dairy foods: Camel. Pages 351-357 in Encyclopedia of Dairy Science. 2nd ed. J. W. Fuquay, P. F. Fox, and P. L. H. McSweeney, ed. Academic Press.

Alston-Mills, B. P. 1995. Comparative analysis of nonhuman milks. C. Comparative analysis of milks used for human consumption. Pages 828-837 in Handbook of Milk Composition. R. G. Jensen, ed. Academic Press. https://doi.org/10.1016/B978-012384430-9/50037-8.

Amalfitano, N., C. Cipolat-Gotet, A. Cecchinato, M. Malacarne, A. Summer, and G. Bittante. 2019. Milk protein fractions strongly affect the patterns of coagulation, curd firming, and syneresis. J. Dairy Sci. 102:2903-2917. https://doi.org/10.3168/jds.2018-15524.

AOAC International. 1995. Official Methods of Analysis. 16th ed. AOAC International. https://doi.org/10.1016/0924-2244(95)90022 -5 .

Ariota, B., G. Campanile, A. Potena, R. Napolano, B. Gasparrini, G. L. Neglia 1, and R. Di Palo. 2007. Ca and P in buffalo milk: Curd yield and milk clotting parameters. Ital. J. Anim. Sci. 6(Suppl. 1):497-499. https://doi.org/10.4081/ijas.2007.1s.497.

Arora, S., and Y. Khetra. 2017. Buffalo milk cheese. Pages 1093-1101 in Cheese: Chemistry, Physics and Microbiology. 4th ed. P. L. H. McSweeney, P. F. Fox, P. D. Cotter, and D. W. Everett, ed. Elsevier. https://doi.org/10.1016/B978-0-12-417012-4.00042-9.

Aspilcueta-Borquis, R. R., R. Di Palo, F. R. Araujo Neto, F. Baldi, G. M. F. de Camargo, L. G. de Albuquerque, L. Zicarelli, and H. Tonhati. 2010. Genetic parameter estimates for buffalo milk yield, milk quality and mozzarella production and Bayesian inference analysis of their relationships. Genet. Mol. Res. 9:1636-1644. https://doi.org/10.4238/vol9-3gmr846.

Bertino, E., L. Cavallarin, F. Cresi, P. Tonetto, C. Peila, G. Ansaldi, M. Raia, A. Varalda, M. Giribaldi, A. Conti, S. Antoniazzi, G. E. Moro, E. Spada, S. Milani, and A. Coscia. 2019. A novel donkey milk-derived human milk fortifier in feeding preterm infants: A randomized controlled trial. J. Pediatr. Gastroenterol. Nutr. 68:116-123. https://doi.org/10.1097/MPG.0000000000002168.

Bittante, G., C. Cipolat-Gotet, F. Malchiodi, E. Sturaro, F. Tagliapietra, S. Schiavon, and A. Cecchinato. 2015. Effect of dairy farming system, herd, season, parity, and days in milk on modeling of the coagulation, curd firming, and syneresis of bovine milk. J. Dairy Sci. 98:2759-2774. https://doi.org/10.3168/jds.2014-8909.

Bittante, G., B. Contiero, and A. Cecchinato. 2013. Prolonged observation and modelling of milk coagulation, curd firming, and syneresis. Int. Dairy J. 29:115-123. https://doi.org/10.1016/j.idairyj 2012.10.007.

Bittante, G., E. Pellattiero, F. Malchiodi, C. Cipolat-Gotet, M. Pazzola, G. M. Vacca, S. Schiavon, and A. Cecchinato. 2014. Quality traits and modeling of coagulation, curd firming, and syneresis of sheep milk of Alpine breeds fed diets supplemented with rumen- protected conjugated fatty acid. J. Dairy Sci. 97:4018-4028. https: //doi.org/10.3168/jds.2013-7345.

Bornaz, S., A. Sahli, A. Attalah, and H. Attia. 2009. Physicochemical characteristics and renneting properties of camels' milk: A comparison with goats', ewes' and cows' milks. Int. J. Dairy Technol. 62:505-513. https://doi.org/10.1111/j.1471-0307.2009.00535.x.

Bouazizi, A., T. Ben Touati, C. Guesmi, H. Attia, and I. Felfoul. 2021. Physicochemical, sensory and coagulation properties of dromedary and cows' skim milk white brined cheeses. Int. Dairy J. 117:105006. https://doi.org/10.1016/j.idairyj.2021.105006.

Brody, S. 1945. Bioenergetics and Growth. Hafner Publ. Co.

Calvo, M. M., and E. Balcones. 2000. Some factors influencing the syneresis of bovine, ovine, and caprine milks. J. Dairy Sci. 83:17331739. https://doi.org/10.3168/jds.S0022-0302(00)75043-0.

Cecchinato, A., A. Albera, C. Cipolat-Gotet, A. Ferragina, and G. Bittante. 2015. Genetic parameters of cheese yield and curd nutrient recovery or whey loss traits predicted using Fourier-transform infrared spectroscopy of samples collected during milk recording on Holstein, Brown Swiss, and Simmental dairy cows. J. Dairy Sci. 98:4914-4927. https://doi.org/10.3168/jds.2014-8599.

Cecchinato, A., C. Cipolat-Gotet, J. Casellas, M. Penasa, A. Rossoni, and G. Bittante. 2013. Genetic analysis of rennet coagulation time, curd-firming rate, and curd firmness assessed over an extended testing period using mechanical and near-infrared instruments. J. Dairy Sci. 96:50-62. https://doi.org/10.3168/jds.2012-5784.

Cecchinato, A., M. Penasa, C. Cipolat-Gotet, M. De Marchi, and G. Bittante. 2012. Short communication: Factors affecting coagulation properties of Mediterranean buffalo milk. J. Dairy Sci. 95:1709-1713. https://doi.org/10.3168/jds.2011-4694.

Cipolat-Gotet, C., G. Bittante, and A. Cecchinato. 2015. Phenotypic analysis of cheese yields and nutrient recoveries in the curd of buffalo milk, as measured with individual model cheese-manufacturing process. J. Dairy Sci. 98:633-645. https://doi.org/10.3168/ jds.2014-8308

Cipolat-Gotet, C., A. Cecchinato, M. Malacarne, G. Bittante, and A. Summer. 2018. Variations in milk protein fractions affect the efficiency of the cheese-making process. J. Dairy Sci. 101:8788-8804. https://doi.org/10.3168/jds.2018-14503.

Cipolat-Gotet, C., A. Cecchinato, M. Pazzola, M. L. Dettori, G. Bittante, and G. M. Vacca. 2016a. Potential influence of herd and animal factors on the yield of cheese and recovery of components from Sarda sheep milk, as determined by a laboratory bench-top model cheese-making. Int. Dairy J. 63:8-17. https://doi.org/10 .1016/j.idairyj.2016.07.013.

Cipolat-Gotet, C., A. Cecchinato, G. Stocco, and G. Bittante. 2016b. The 9-MilCA method as a rapid, partly automated protocol for simultaneously recording milk coagulation, curd firming, syneresis, cheese yield, and curd nutrients recovery or whey loss. J. Dairy Sci. 99:1065-1082. https://doi.org/10.3168/jds.2015-9734.

Cipolat-Gotet, C., M. Malacarne, A. Summer, A. Cecchinato, and G. Bittante. 2020. Modeling weight loss of cheese during ripening and the influence of dairy system, parity, stage of lactation, and composition of processed milk. J. Dairy Sci. 103:6843-6857. https:// doi.org/10.3168/jds.2019-17829.

D'Alessandro, A. G., G. Martemucci, P. Loizzo, and M. Faccia. 2019. Production of cheese from donkey milk as influenced by addition of transglutaminase. J. Dairy Sci. 102:10867-10876. https://doi.org/ 10.3168/jds.2019-16615.

Dettori, M. L., L. Milone, C. Grassi, F. Zicarelli, R. Napolano, A. Giovane, and R. Di Palo. 2009. Milk protein and cheese yield in buffalo species. Ital. J. Anim. Sci. 8(Suppl. 2):381-383. https://doi .org/10.4081/ijas.2009.s2.381.

Devendra, C., and G. F. W. Haenlein. 2011. Animals that produce dairy foods: Goat breeds. Pages 310-324 in Encyclopedia of Dairy Science. 2nd ed. J. W. Fuquay, P. F. Fox, and P. L. H. McSweeney, ed. Academic Press. https://doi.org/10.1016/B978-0-12-374407-4 $.00035-2$.

Devle, H., I. Vetti, C. F. Naess-Andresen, E.-O. Rukke, G. Vegarud, and D. Ekeberg. 2012. A comparative study of fatty acid profiles in ruminant and non-ruminant milk. Eur. J. Lipid Sci. Technol. 114:1036-1043. https://doi.org/10.1002/ejlt.201100333. 
Dias, C., and L. Mendes. 2018. Protected Designation of Origin (PDO), Protected Geographical Indication (PGI) and Traditional Speciality Guaranteed (TSG): A bibiliometric analysis. Food Res. Int. 103:492-508. https://doi.org/10.1016/j.foodres.2017.09.059.

Doreau, M., and W. Martin-Rosset. 2011. Animals that produce dairy foods: Horse. Pages 358-364 in Encyclopedia of Dairy Science. 2nd ed. J. W. Fuquay, P. F. Fox, and P. L. H. McSweeney, ed. Academic Press. https://doi.org/10.1016/B978-0-12-374407-4.00040-6.

Faccia, M., A. G. D'Alessandro, A. Summer, and Y. Hailu. 2020a Milk products from minor dairy species: A review. Animals (Basel) 10:1260. https://doi.org/10.3390/ani10081260.

Faccia, M., G. Gambacorta, G. Martemucci, G. Difonzo, and A. G. D'Alessandro. 2020b. Chemical-sensory traits of fresh cheese made by enzymatic coagulation of donkey milk. Foods 9:16. https://doi .org/10.3390/foods9010016.

Faccia, M., G. Gambacorta, G. Martemucci, G. Natrella, and A. G. D'Alessandro. 2018. Technological attempts at producing cheese from donkey milk. J. Dairy Res. 85:327-330. https://doi.org/10 .1017/S0022029918000420.

Fahmy, M. H., and N. B. Shrestha. 2002. Animals that produce dairy foods: Sheep breeds. Pages 325-339 in Encyclopedia of Dairy Science. 2nd ed. J. W. Fuquay, P. F. Fox, and P. L. H. McSweeney, ed. Academic Press. https://doi.org/10.1016/B978-0-12-374407-4 .00036-4.

FAO (Food and Agriculture Organization of the United Nations). 2019. Gateway to dairy production and products. Accessed Dec. 1, 2021. http://www.fao.org/dairy-production-products/production/ dairy-animals/en/.

Geiger, R. 1954. Klassifikation der Klimate nach W. Köppen [Classification of climates after W. Köppen]. Pages 603-607 in LandoltBörnstein - Zahlenwerte und Funktionen aus Physik, Chemie, Astronomie, Geophysik und Technik, alte Serie. Springer.

Gelè, M., S. Minery, J.-M. Astruc, P. Brunschwig, M. FerrandCalmels, G. Lagriffoul, H. Larroque, J. Legarto, O. Leray, P. Martin, G. Miranda, I. Palhiere, P. Trossat, and M. Brochard. 2014. Phénotypage et génotypage à grande échelle de la composition fine des laits dans les filières bovine, ovine et caprine [Large-scale phenotyping and genotyping of milk fine composition in the cow, goat and ewe]. INRA Prod. Anim. 27:255-268. https://doi.org/10 .20870/productions-animales.2014.27.4.3072.

Haddi, M. L., S. Filacorda, K. Meniai, F. Rollin, and P. Susmel. 2003. In vitro fermentation kinetics of some halophyte shrubs sampled at three stage of maturity. Anim. Feed Sci. Technol. 104:215-225. https://doi.org/10.1016/S0377-8401(02)00323-1.

Iannella, G. 2015. Donkey cheese made through pure camel chymosin. Afr. J. Food Sci. 9:421-425. https://doi.org/10.5897/AJFS2015 1322.

IDF. 2020. The world dairy situation, 2018. Bulletin of the International Dairy Federation, 494/2018. IDF. https://doi.org/10.1111/ 1471-0307.12662.

Kappeler, S. R., H. J. van den Brink, H. Rahbek-Nielsen, Z. Farah, Z. Puhan, E. B. Hansen, and E. Johansen. 2006. Characterization of recombinant camel chymosin reveals superior properties for the coagulation of bovine and camel milk. Biochem. Biophys. Res. Commun. 342:647-654. https://doi.org/10.1016/j.bbrc.2006.02.014.

Khan, M. S. 2002. Animals that produce dairy foods: Water buffalo. Pages 340-342 in Encyclopedia of Dairy Science. 2nd ed. J. W. Fuquay, P. F. Fox, and P. L. H. McSweeney, ed. Academic Press. https://doi.org/10.1016/B978-0-12-374407-4.00037-6.

Langholm Jensen, J., A. Molgaard, J.-C. Navarro Poulsen, M. K. Harboe, J. B. Simonsen, A. M. Lorentzen, K. Hjerno, K. B. van den Brink, K. B. Qvist, and S. Larsen. 2013. Camel and bovine chymosin: The relationship between their structures and cheese-making properties. Acta Crystallogr. D Biol. Crystallogr. 69:901-913. https://doi.org/10.1107/S0907444913003260.

Legarto, J., M. Gelè, A. Ferlay, C. Hurtaud, G. Lagriffoul, I. Palhiere, J.-L. Peyraud, B. Rouillè, and P. Brunschwig. 2014. Effets des conduites d'élevage sur la production de lait, las taux butyreux et protéique et la composition en acides gras du lait de vache, chèvre et brebis évaluée par spectrométrie dans le moyen infra- rouge. INRA Prod. Anim. 27:269-282. https://doi.org/10.20870/ productions-animales.2014.27.4.3073.

Leitner, G., Y. Lavon, Z. Matzrafi, O. Benun, D. Bezman, and U. Merin. 2016. Somatic cell counts, chemical composition and coagulation properties of goat and sheep bulk tank milk. Int. Dairy J. 58:9-13. https://doi.org/10.1016/j.idairyj.2015.11.004.

Liburdi, K., C. Boselli, G. Giangolini, S. Amatiste, and M. Esti. 2019. An evaluation of the clotting properties of three plant rennets in the milk of different animal species. Foods 8:600. https://doi.org/ 10.3390/foods8120600.

Lomer, M. C. G. C. Parkes, and J. D. Sanderson. 2008. Review article: Lactose intolerance in clinical practice - myths and realities. Aliment. Pharmacol. Ther. 27:93-103. https://doi.org/10.1111/j .1365-2036.2007.03557.x.

Manca, M. G., J. Serdino, G. Gaspa, P. Urgeghe, I. Ibba, M. Contu, P. Fresi, and N. P. P. Macciotta. 2016. Derivation of multivariate indices of milk composition, coagulation properties, and individual cheese yield in dairy sheep. J. Dairy Sci. 99:4547-4557. https://doi .org/10.3168/jds.2015-10589.

Martini, M., J. Altomonte, R. Licitra, and F. Salari. 2018. Nutritional and nutraceutical quality of donkey milk. J. Equine Vet. Sci. 65:33-37. https://doi.org/10.1016/j.jevs.2017.10.020.

Medhammar, E., R. Wijesinha-Bettoni, B. Stadlmayr, E. Nilsson, U. R. Charrondiere, and B. Burlingame. 2012. Composition of milk from minor dairy animals and buffalo breeds: A biodiversity perspective. J. Sci. Food Agric. 92:445-474. https://doi.org/10.1002/ jsfa. 4690 .

Moatsou, G., and Y. W. Park. 2017. Goat milk products: Types of products, manufacturing technology, chemical composition, and marketing. Pages 84-150 in Handbook of Milk of Non-Bovine Mammals. 2nd ed. Y. W. Park, G. F. W. Haenlein, and W. L. Wendorff, ed. John Wiley \& Sons, Ltd. https://doi.org/10.1002/ 9781119110316.ch2.3.

Monti, G., E. Bertino, M. C. Muratore, A. Coscia, F. Cresi, L. Silvestro, C. Fabris, D. Fortunato, M. G. Giuffrida, and A. Conti. 2007. Efficacy of donkey's milk in treating highly problematic cow's milk allergic children: An in vivo and in vitro study. Pediatr. Allergy Immunol. 18:258-264. https://doi.org/10.1111/j.1399-3038.2007 $.00521 . \mathrm{x}$

Murgia, A., P. Scano, M. Contu, I. Ibba, M. Altea, M. Bussu, M. Demuru, A. Porcu, and P. Caboni. 2016. Characterization of donkey milk and metabolite profile comparison with human milk and formula milk. Lebensm. Wiss. Technol. 74:427-433. https://doi.org/ 10.1016/j.lwt.2016.07.070

Noce, A., M. Pazzola, M. L. Dettori, M. Amills, A. Castello, A. Cecchinato, G. Bittante, and G. M. Vacca. 2016. Variations at regulatory regions of the milk protein genes are associated with milk traits and coagulation properties in the Sarda sheep. Anim. Genet. 47:717-726. https://doi.org/10.1111/age.12474.

NRC. 2001 Nutrient Requirements of Dairy Cattle. 7th rev. ed. Natl. Acad. Press. https://doi.org/10.17226/9825.

Oftedal, O. T., and S. J. Iverson. 1995. Comparative analysis of nonhuman milks: A phylogenetic variation in the gross composition of milk. Pages 749-789 in Handbook of Milk Composition. R. G. Jensen, ed. Academic Press. https://doi.org/10.1016/B978-012384430 $-9 / 50035-4$.

Omar, A., N. Harbourne, and M. Oruna-Concha. 2016. Quantification of major camel milk proteins by capillary electrophoresis. Int Dairy J. 58:31-35. https://doi.org/10.1016/j.idairyj.2016.01.015.

Omar, A., N. Harbourne, and M. J. Oruna-Concha. 2018. Effects of industrial processing methods on camel skimmed milk properties. Int. Dairy J. 84:15-22. https://doi.org/10.1016/j.idairyj.2018.03 .011 .

Othmane, M. H., L. F. De La Fuente, J. A. Carriedo, and F. San Primitivo. 2002. Heritability and genetic correlations of test day milk yield and composition, individual laboratory cheese yield, and somatic cell count for dairy ewes. J. Dairy Sci. 85:2692-2698. https://doi.org/10.3168/jds.S0022-0302(02)74355-5.

Park, Y. W., G. F. W. Haenlein, and W. L. Wendorff. 2017. Overview of milk of non-bovine mammals. Pages 1-9 in Handbook of Milk 
of Non-Bovine Mammals. 2nd ed. Y. W. Park, G. F. W. Haenlein, and W. L. Wendorff, ed. John Wiley \& Sons, Ltd. https://doi.org/ 10.1002/9781119110316.ch1.

Pazzola, M. 2019. Coagulation traits of sheep and goat milk. Animals (Basel) 9:540. https://doi.org/10.3390/ani9080540.

Pazzola, M., M. L. Dettori, C. Cipolat-Gotet, A. Cecchinato, G. Bittante, and G. M. Vacca. 2014. Phenotypic factors affecting coagulation properties of milk from Sarda ewes. J. Dairy Sci. 97:72477257. https://doi.org/10.3168/jds.2014-8138.

Pazzola, M., G. Stocco, M. L. Dettori, G. Bittante, and G. M. Vacca. 2019. Effect of goat milk composition on cheesemaking traits and daily cheese production. J. Dairy Sci. 102:3947-3955. https://doi .org/10.3168/jds.2018-15397.

Pazzola, M., G. Stocco, P. Paschino, M. L. Dettori, C. Cipolat-Gotet, G. Bittante, and G. M. Vacca. 2018. Modeling of coagulation, curd firming, and syneresis of goat milk from 6 breeds. J. Dairy Sci. 101:7027-7039. https://doi.org/10.3168/jds.2018-14397.

Qadeer, Z., N. Huma, A. Sameen, and T. Iqbal. 2019. Influence of pasteurization temperature, $\mathrm{pH}, \mathrm{CaCl} 2$ and blending of buffalo milk on the rennet coagulation time (RCT), yield and texture of camel milk cheese. Pak. J. Agric. Sci. 56:141-147. https://doi.org/ 10.21162/PAKJAS/19.6551.

Ramet, J. P. 2001. The technology of making cheese from camel milk (Camelus dromedarius). FAO Animal Production and Health Paper No. 113. FAO.

Ribadeau-Dumas, B., and R. Grappin. 1989. Milk protein analysis. Lait 69:357-416. https://doi.org/10.1051/lait:1989527.

Roca-Saavedra, P., P. Mariño-Lorenzo, J. M. Miranda, J. J. PortoArias, A. Lamas, B. I. Vazquez, C. M. Franco, and A. Cepeda. 2017. Phytanic acid consumption and human health, risks, benefits and future trends: A review. Food Chem. 221:237-247. https: //doi.org/10.1016/j.foodchem.2016.10.074.

Roy, D., A. Ye, P. J. Moughan, and H. Singh. 2020. Gelation of milks of different species (dairy cattle, goat, sheep, red deer, and water buffalo) using glucono- $\delta$-lactone and pepsin. J. Dairy Sci. 103:5844-5862. https://doi.org/10.3168/jds.2019-17571.

Sakandar, H. A., S. Ahmad, R. Perveen, H. K. W. Aslam, A. Shakeel, F. A. Sadiq, and M. Imran. 2018. Camel milk and its allied health claims: a review. Prog. Nutr. 20(Suppl. 1):15-29. https://doi.org/ 10.23751/pn.v20i1-s.5318.

Salimei, E. 2011. Animals that produce dairy foods: Donkey. Pages 365-373 in Encyclopedia of Dairy Science. 2nd ed. J. W. Fuquay, P. F. Fox, and P. L. H. McSweeney, ed. Academic Press. https:// doi.org/10.1016/B978-0-12-374407-4.00041-8

Salimei, E., and F. Fantuz. 2012. Equid milk for human consumption. Int. Dairy J. 24:130-142. https://doi.org/10.1016/j.idairyj.2011.11 .008 .

Sampaio, P. N. S. 2017. Optimization of clotting donkey milk using an aspartic protease from Cynara cardunculus flowers. J. Adv. Dairy Res. 5:190. https://doi.org/10.4172/2329-888X.1000190.

Schuster-Wolff-Bühring, R., R. Michel, and J. Hinrichs. 2011. A new liquid chromatography method for the simultaneous and sensitive quantification of lactose and lactulose in milk. Dairy Sci. Technol. 91:27-37. https://doi.org/10.1051/dst/2010034.

Sørensen, J., D. S. Palmer, K. B. Qvist, and B. Schiott. 2011. Initial stage of cheese production: A molecular modeling study of bovine and camel chymosin complexed with peptides from the chymosinsensitive region of $\kappa$-casein. J. Agric. Food Chem. 59:5636-5647. https://doi.org/10.1021/jf104898w.

Souroullas, K., M. Aspri, and P. Papademas. 2018. Donkey milk as a supplement in infant formula: Benefits and technological challeng- es. Food Res. Int. 109:416-425. https://doi.org/10.1016/j.foodres .2018.04.051.

Stocco, G., C. Cipolat-Gotet, T. Bobbo, A. Cecchinato, and G. Bittante. 2017. Breed of cow and herd productivity affect milk composition and modeling of coagulation, curd firming, and syneresis. J. Dairy Sci. 100:129-145. https://doi.org/10.3168/jds.2016-11662.

Stocco, G., C. Cipolat-Gotet, V. Gasparotto, A. Cecchinato, and G. Bittante. 2018a. Breed of cow and herd productivity affect milk nutrient recovery in curd, and cheese yield, efficiency and daily production. Animal 12:434-444. https://doi.org/10.1017/ S1751731117001471.

Stocco, G., M. Pazzola, M. L. Dettori, P. Paschino, G. Bittante, and G. M. Vacca. 2018b. Effect of composition on coagulation, curd firming, and syneresis of goat milk. J. Dairy Sci. 101:9693-9702. https://doi.org/10.3168/jds.2018-15027.

Sun, Q., J.-P. Lv, L. Liu, S. Zhang, X. Liang, and J. Lu. 2014. Comparison of milk samples collected from some buffalo breeds and crossbreds in China. Dairy Sci. Technol. 94:387-395. https://doi .org/10.1007/s13594-013-0159-9.

Tempelman, R. J., and Y. Lu. 2020. Symposium review: Genetic relationships between different measures of feed efficiency and the implications for dairy cattle selection indexes. J. Dairy Sci. 103:53275345. https://doi.org/10.3168/jds.2019-17781.

Vacca, G. M., M. Pazzola, M. L. Dettori, E. Pira, F. Malchiodi, C. Cipolat-Gotet, A. Cecchinato, and G. Bittante. 2015. Modeling of coagulation, curd firming, and syneresis of milk from Sarda ewes. J. Dairy Sci. 98:2245-2259. https://doi.org/10.3168/jds.2014 $-8902$.

Vacca, G. M., G. Stocco, M. L. Dettori, G. Bittante, and M. Pazzola. 2020. Goat cheese yield and recovery of fat, protein, and total solids in curd are affected by milk coagulation properties. J. Dairy Sci. 103:1352-1365. https://doi.org/10.3168/jds.2019-16424.

Vacca, G. M., G. Stocco, M. L. Dettori, E. Pira, G. Bittante, and M. Pazzola. 2018a. Milk yield, quality, and coagulation properties of 6 breeds of goats: Environmental and individual variability. J. Dairy Sci. 101:7236-7247. https://doi.org/10.3168/jds.2017-14111.

Vacca, G. M., G. Stocco, M. L. Dettori, A. Summer, C. Cipolat-Gotet, G. Bittante, and M. Pazzola. 2018b. Cheese yield, cheesemaking efficiency, and daily production of 6 breeds of goats. J. Dairy Sci. 101:7817-7832. https://doi.org/10.3168/jds.2018-14450.

VDLUFA. 2003. Methodenbuch Band VI: Chemische, physikalische und mikrobiologische Untersuchungsverfahren für Milch, Milchprodukte und Molkereihilfsstoffe. VDLUFA-Verlag.

Vincenzetti, S., P. Polidori, P. Mariani, N. Cammertoni, F. Fantuz, and A. Vita. 2008. Donkey's milk protein fractions characterization. Food Chem. 106:640-649. https://doi.org/10.1016/j .foodchem.2007.06.026.

Wanders, R. J. A., J. Komen, and S. Ferdinandusse. 2011. Phytanic acid metabolism in health and disease. Biochim. Biophys. Acta Mol. Cell Biol. Lipids 1811:498-507. https://doi.org/10.1016/j .bbalip.2011.06.006.

Zarrin, M., J. L. Riveros, A. Ahmadpour, A. M. de Almeida, G. Konuspayeva, E. Vargas-Bello-Pérez, B. Faye, and L. E. HernándezCastellano. 2020. Camelids: New players in the international animal production context. Trop. Anim. Health Prod. 52:903-913. https://doi.org/10.1007/s11250-019-02197-2.

Zicarelli, L. 2004. Buffalo milk: Its proprieties, dairy yield and mozzarella production. Vet. Res. Commun. 28:127-135. https://doi.org/ 10.1023/B:VERC.0000045390.81982.4d. 